\title{
Casas de vivenda e de morada: estilo de construção e interior das residências da elite escravista sul-mineira - século XIX'
}

\author{
Marcos Ferreira de Andrade \\ Programa de pós-graduação em História \\ da Universidade Federal Fluminense e \\ Depto. de História da Universidade do \\ Estado de Minas Gerais - unidade de Campanha
}

RESUMO: Este artigo tem por objetivo investigar aspectos da cultura material da elite escravista do sul de Minas, com destaque para as transformações ocorridas no exterior e interior das casas de moradas. A região passou por significativas transformações após a chegada da Corte ao Brasil, em 1808. Verificou-se uma intensificação do comércio de gêneros voltados para o abastecimento da praça mercantil do Rio de Janeiro, o que possibilitou a ascensão socioeconômica e política de alguns proprietários daquela área ao longo das primeiras décadas do século XIX.

PALAVRAS-CHAVE: História. Cultura material. Elite escravista. Sul de Minas.

ABSTRACT: This article aims at investigating some aspects of the material culture of the slaving elite from Southern Minas Gerais, with a special attention given to the changes that took place both in the outside and the inside of slave houses. The region suffered considerable changes after the Portuguese court came to Brazil in 1808. There was an intensification of the commerce of those goods directed to supplying the markets of Rio de Janeiro, which allowed for the social-economic and political ascension of some land- and slave-owners from that area along the first decades of the 19th Century.

KEYWORDS: History. Material Culture. Slaving Elite. Southern Minas Gerais.

Pretendo destacar alguns aspectos do cotidiano das famílias da elite do sul de Minas, seguindo os passos daquilo que antropólogos e arqueólogos definem como cultura material, ou seja, verificar, por meio dos indícios encontrados nos documentos, pistas sobre o estilo de construção e o que havia no interior

1. Este texto é parte de um dos capítulos de minha tese de doutorado, em fase de finalização na Universidade Federal Fluminense, em que investigo a cultura material e os modos de vida da elite rural sul-mineira, na primeira metade do século XIX. 
das casas de vivenda e de morada (sedes de fazendas e sobrados nas vilas), na primeira metade do século XIX (BURKE, 2001 ; BRAUDEL, 1970; FREYRE, 1961 1). Para desvendar parte desse universo serão analisadas várias fontes apresentadas e confrontadas ao longo do texto, entre elas: inventários, relatos dos viajantes, correspondências particulares, genealogias e memórias.

Os inventários são fontes primordiais para esse tipo de investigação e já foram pioneiramente utilizados por Machado (1980), que, em muitos pontos de sua clássica obra, preocupou-se em desvendar aspectos do cotidiano dos bandeirantes paulistas e perceber as transformações ao longo do período trabalhado. Também estarei atento às inúmeras mudanças que ocorreram na conjuntura nacional e internacional da primeira metade do século XIX e como isso, de algum modo, interferia nos costumes da elite interiorana, em algumas vilas e fazendas. Os "trastes", expressão recorrente nos inventários para discriminar os bens existentes no interior das residências, apresentavam sinais claros de uma mudança nos costumes, nos modos de se vestir e até mesmo de decorar o interior das casas.

Procurarei dar conta da distância de um passado que não nos é tão distante assim, mas que apresenta profundos contrastes com o nosso modo de vida atual. Guardadas as devidas diferenças no espaço e no tempo, as afirmações de Braudel (1970), ao se dedicar aos pormenores da vida material na Europa, entre os séculos XV e XVIII, cabem perfeitamente no contexto que irei investigar, ou seja, entre o nosso passado e a atualidade "surgiram tremendas distâncias: a iluminação da noite, o aquecimento, os transportes, a alimentação, as doenças e os medicamentos" (BRAUDEL, 1970, p. 16). Também estarei atento a permanências, hábitos e práticas seculares, que, apesar das inúmeras mudanças ocorridas em nosso século, ainda podem ser vistos na paisagem interiorana mineira, atualmente bastante valorizada e com novo significado cultural e social.

Sobre o estilo e o padrão de construção das sedes de fazendas em Minas, Saint-Hilaire (1976) apontou uma distinção entre aquelas da região aurífera e as da comarca do Rio das Mortes. As primeiras se assemelhavam um pouco com os castelos de seu país, e as últimas, com as granjas. Na sua descrição, ele ressaltou os seguintes aspectos:

Um muro de pedras rústicas mais ou menos da altura de um homem cerca um pátio bastante vasto, no fundo do qual se enfileiram as choças dos escravos, os galpões para beneficiamento ou depósito de produtos agrícolas e a casa-grande. Esta, de pau-a-pique e coberta com telhas, é construída ao rés do chão (SAINTTHILAIRE, 1976, p. 56).

Assim também o era na região de Vassouras, antes da expansão cafeeira. Alguns dos primeiros povoadores da área procediam de Minas Gerais e traziam consigo o estilo simples das construções do período colonial e da primeira metade do século XIX. As fazendas eram quase sempre construídas aos sopés dos morros, próximas às quedas-d'águas, destinadas a fornecer força hidráulica para moinhos, monjolos e engenhos. Além da casa de vivenda, sede da propriedade, e das senzalas, havia uma série de benfeitorias que permitiam o funcionamento da fazenda, tais como: paióis, casas de tropa, moinhos, 
monjolos, estrebarias, chiqueiros, etc. A rusticidade foi a marca inicial dessas construções, que utilizavam do material disponível na região, ou seja, madeiras, pedras, cipós, etc.

As vigas dos cantos das paredes eram de madeira, toscamente cortadas, e os espaços preenchidos com escoras verticais de madeira de palmeira, através das quais estavam atadas tiras da mesma madeira. Como o metal era difícil de se obter e o transporte por mulas era trabalhoso e caro, usava-se cipó (cipó-de-são-joão) para atar as traves transversais da palmeira às estacas. Sobre esta estrutura atirava-se o barro, criando a construção pau-apique ou sopapo, comum nessa época no interior brasileiro. A terra batida era o assoalho dos aposentos construídos sobre os fundos do porão, pois tempo e trabalho eram dedicados à pavimentação dos armazéns a fim de evitar que a umidade e os ratos causassem danos à colheita (STEIN, 1990, p. 48).

É evidente que Stein (1990) está se referindo ao processo inicial dessas construções comum no interior mineiro. Também é preciso salientar que algumas sedes de fazendas em Minas Gerais, particularmente no sul, passaram por transformações importantes na sua estrutura de construção, tamanho e estilo, o que indicava um tempo de fortuna e evidência de algumas propriedades.

Faria (1998) apresenta uma discussão detalhada e muito interessante sobre as casas de morada e a pluralidade de habitação nos Campos dos Goitacases, no século XVIII, incluindo figuras que, elaboradas a partir da análise dos inventários, permitem-nos visualizar as unidades agrárias que produziam alimentos, gado ou cana-de-açúcar.

Nos inventários pesquisados, as sedes de fazendas vêm arroladas entre os "bens de raiz", e às vezes a sua descrição apresenta pouco detalhamento, sem maiores informações sobre as casas de vivenda e senzalas. Porém, não se esquecia de mencionar as benfeitorias da propriedade, ressaltando, por exemplo, a existência de casas de tropa e queijos, engenhos, moinhos, monjolos, paióis, etc. Também é possível encontrar informação sobre o tipo de cerca que delimitava a sede da fazenda. Em fazendas mais antigas, a sede era cercada por arvoredos de espinhos e nas mais abastadas, por muro de pedras.

Se por um lado a escassez de informações impossibilita o conhecimento mais detalhado dos padrões de construção, por outro, a importância econômica de algumas construções pode ser constatada tanto pelo valor a elas conferido quanto especialmente pelo número de benfeitorias anexas à casa de vivenda, quase sempre coberta de telhas. Vejamos, por exemplo, o caso da Fazenda Narciso, pertencente à família Junqueira e arrolada entre os bens do barão de Alfenas, em 1868, quando foi realizado o seu inventário.

[...] consta de engenho de cilindros com todos os seus acessórios, engenho de serra com seus pertences movidos por seu competente rego-d'água, moinho e monjolo movido por outro rego, paiol, casas para queijos, um rancho, olaria, fornalha respectiva, tudo coberto de telhas, avaliados em cinco contos, oitocentos e setenta e cinco mil réis [...] (Inv. B $)^{2}$.

Atualmente, algumas dessas sedes, em especial as da família Junqueira, ainda conservam parte da estrutura arquitetônica oitocentista. Evidentemente
2. Agradeço ao dr. José Américo Junqueira de Mattos pelo repasse do xerox desse inventário.A documentação cartorial de Baependi está sob a custódia do Arquivo do Museu Regional de São João del-Rei e atualmente se encontra em fase de organização e descrição. 
3. Um levantamento histórico detalhado das principais fazendas da família Junqueira pode ser en contrado na obra genealógica de Mattos (2004,p 101-138), no primeiro volume, especialmente no capítulo em que o autor discute a formação da raça de cavalos manga-larga na Fazenda Campo Ale gre, de propriedade de Gabriel Francisco Jun queira, o filho caçula do patriarca da família. que não estou desconsiderando as intervenções e mudanças pelas quais elas passaram ao longo dos séculos XIX e XX, mas muito da descrição dos inventários do século XIX ainda pode ser encontrado nas várias fazendas que sobreviveram à ação do tempo ${ }^{3}$. Em diversos casos também se conservou o nome antigo das sedes: Bela Cruz, Boa Vista, Narciso, Favacho, Traituba, Angaí, Campo Lindo. A sede da antiga Fazenda Campo Alegre, que foi de propriedade do deputado Gabriel Francisco Junqueira, já não existe mais. Vejamos, primeiramente, a Fazenda Bela Cruz, palco da grande rebelião dos escravos de 1833 (ANDRADE, 1996, 1998-1999, 2002). Nela, é possível verificar a mesma estrutura descrita nos inventários como os muros de pedra cercando e separando as principais benfeitorias, a importância do curso de água para os moinhos e monjolos, os engenhos e as senzalas de pau-a-pique (Figuras 1 a 7). A sede encontra-se bastante deteriorada em alguns pontos e passou por transformações com a retirada de duas janelas laterais na parte frontal. Trata-se de uma outra sede, construída na segunda metade do século XIX, algumas décadas após a rebelião dos escravos.

Quase todas as fazendas da família conservam uma estrutura bastante semelhante. São construções de um só pavimento, pé-direito muito alto, grandes portais e muitas janelas. A base de sustentação é quase sempre de pedra, e o assoalho é sempre de madeira, sustentado por grandes vigas do mesmo material,

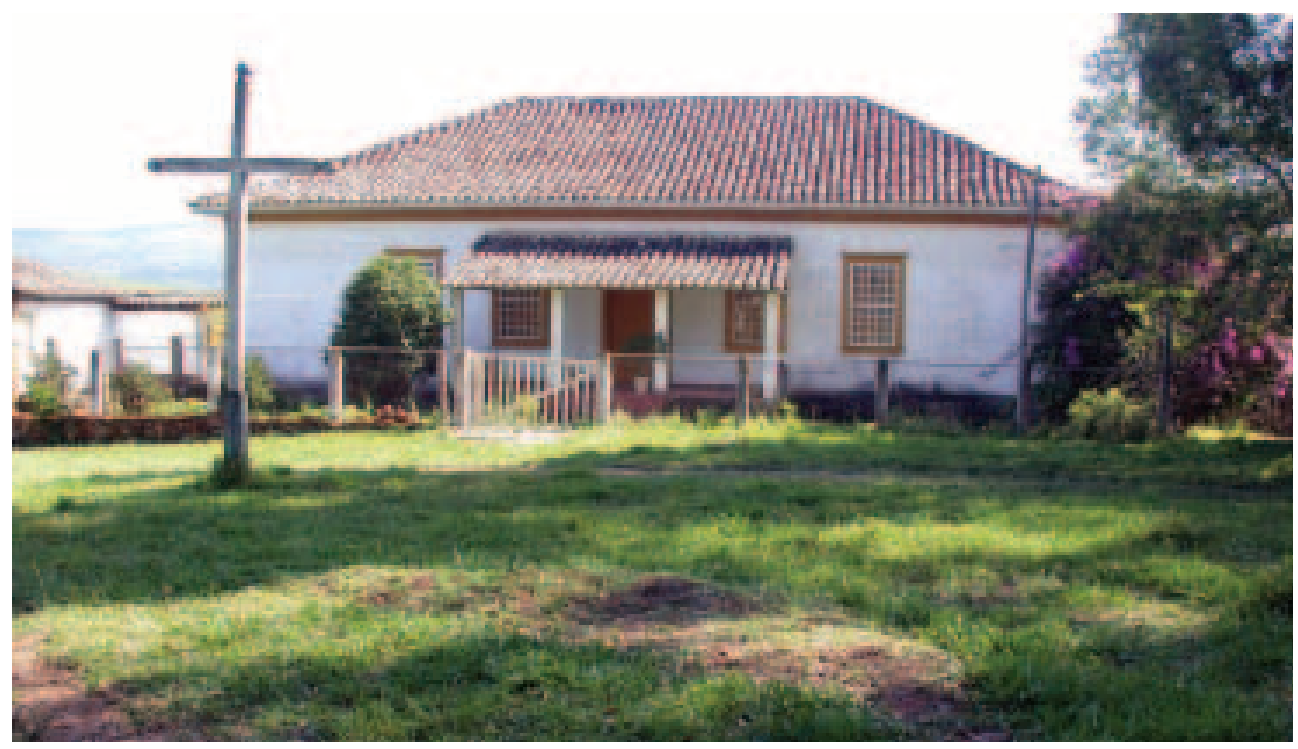

Figura 1 - Vista frontal da Fazenda Bela Cruz. Percebe-se que foram retiradas duas janelas de ambos os lados, que faziam parte da estrutura original da construção. Trata-se assim de uma outra sede, construída na segunda metade do século XIX. Foi nesta fazenda que ocorreu a maior rebelião de escravos do sudeste escravista, em 1833, conhecida como a Revolta de Carrancas. Acervo particular do dr. José Américo Junqueira de Mattos. Foto de Verissimo João Dias Neto (Lilo). Nov./2003. 


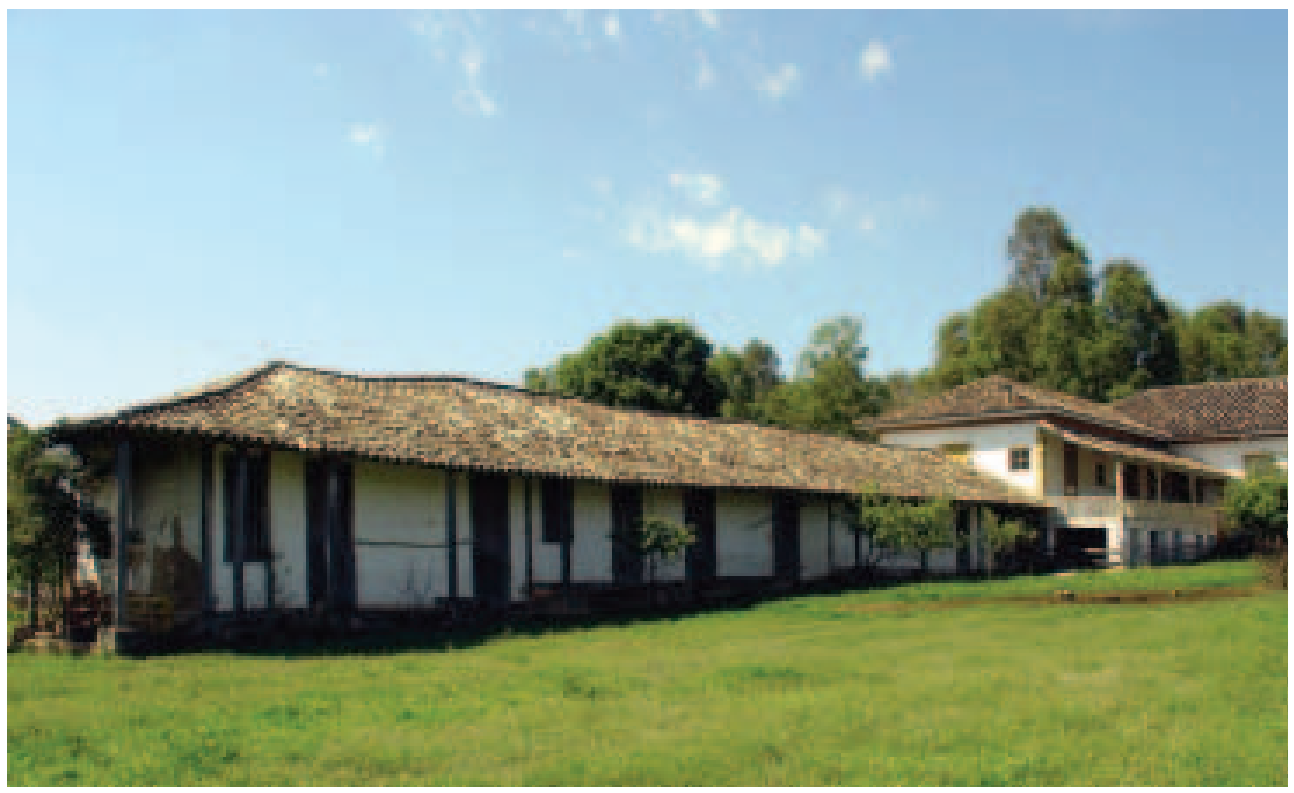

Figura 2 - Uma das senzalas da fazenda, a única que resistiu à ação do tempo. Acervo particular do autor. Nov./2003.

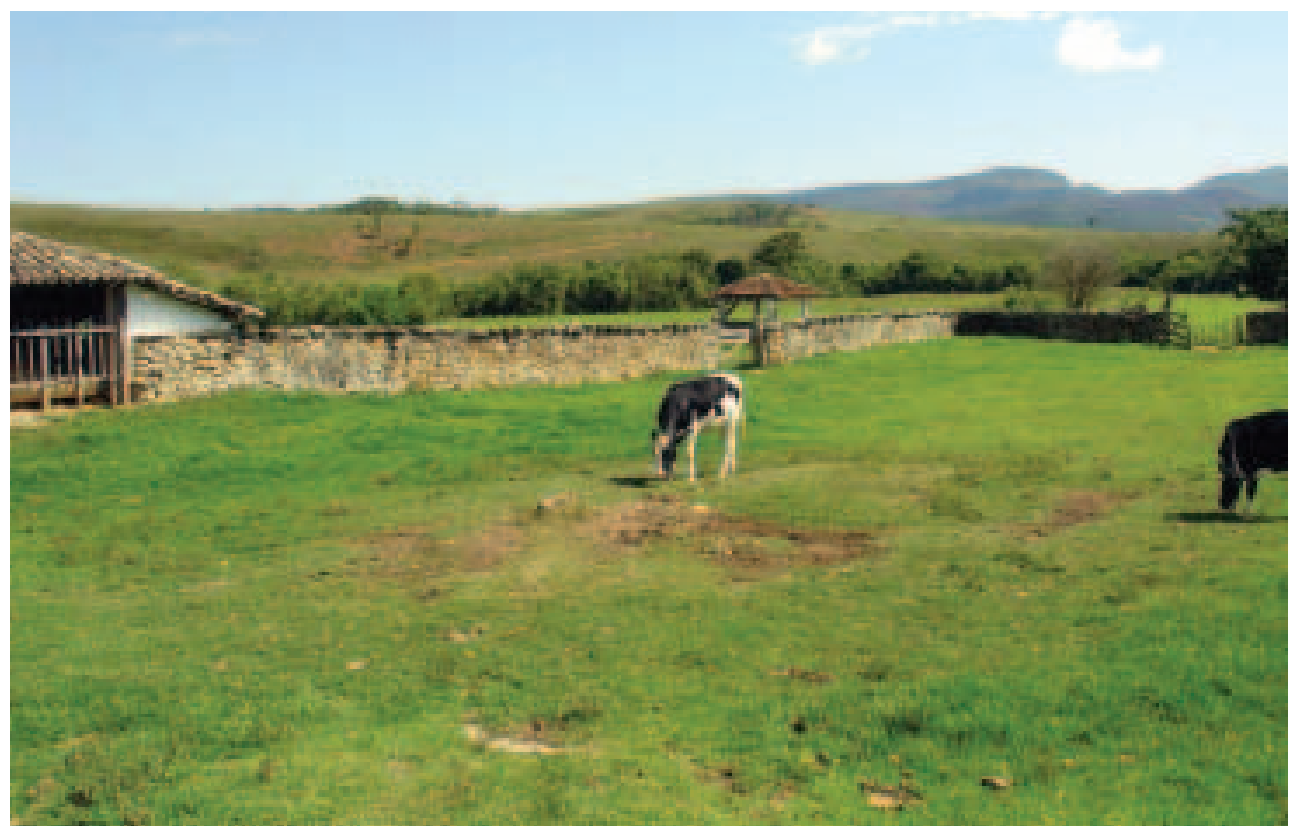

Figura 3 - Detalhe do interior da fazenda, separada por muros de pedra. Acervo particular do autor. Nov./2003. 


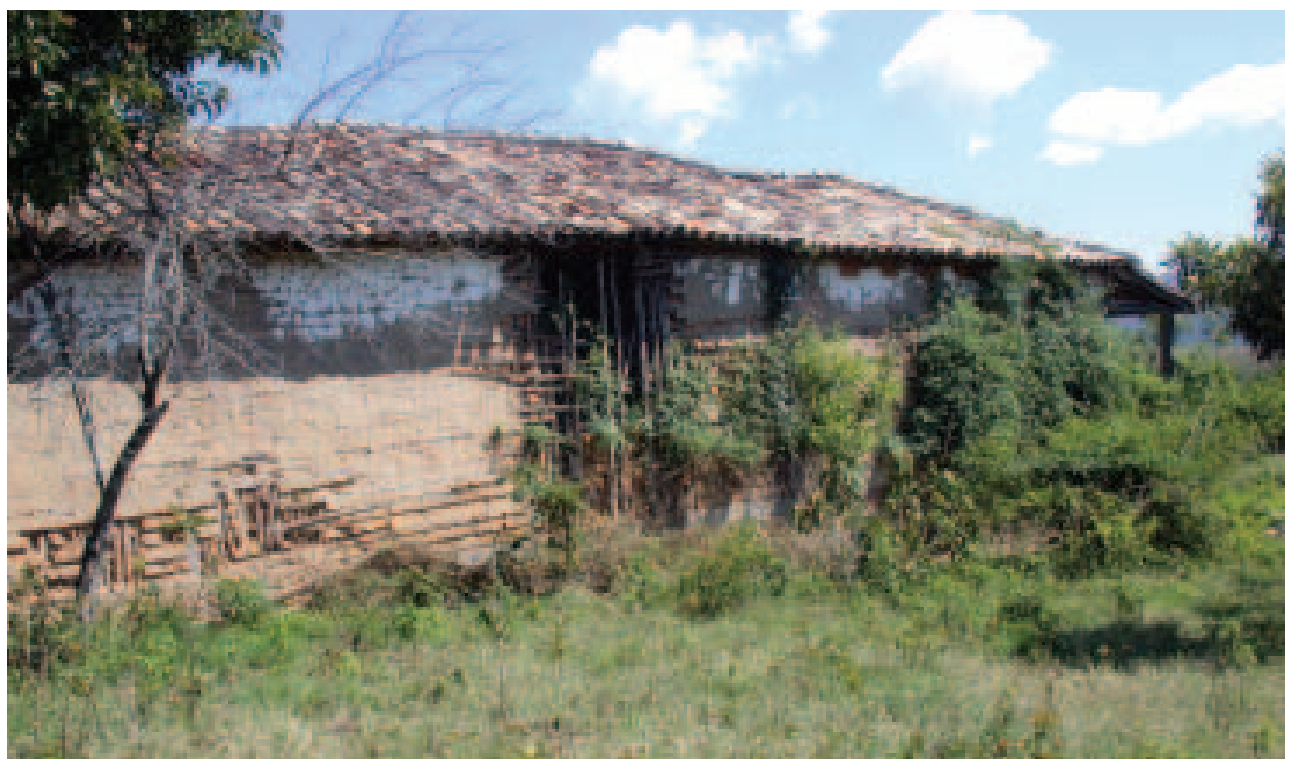

Figura 4 - Vista da senzala pelos fundos. Destaque para a construção de pau-a-pique. Acervo particular do dr. José Américo Junqueira de Mattos. Foto de Verissimo João Dias Neto (Lilo). Nov./2003.

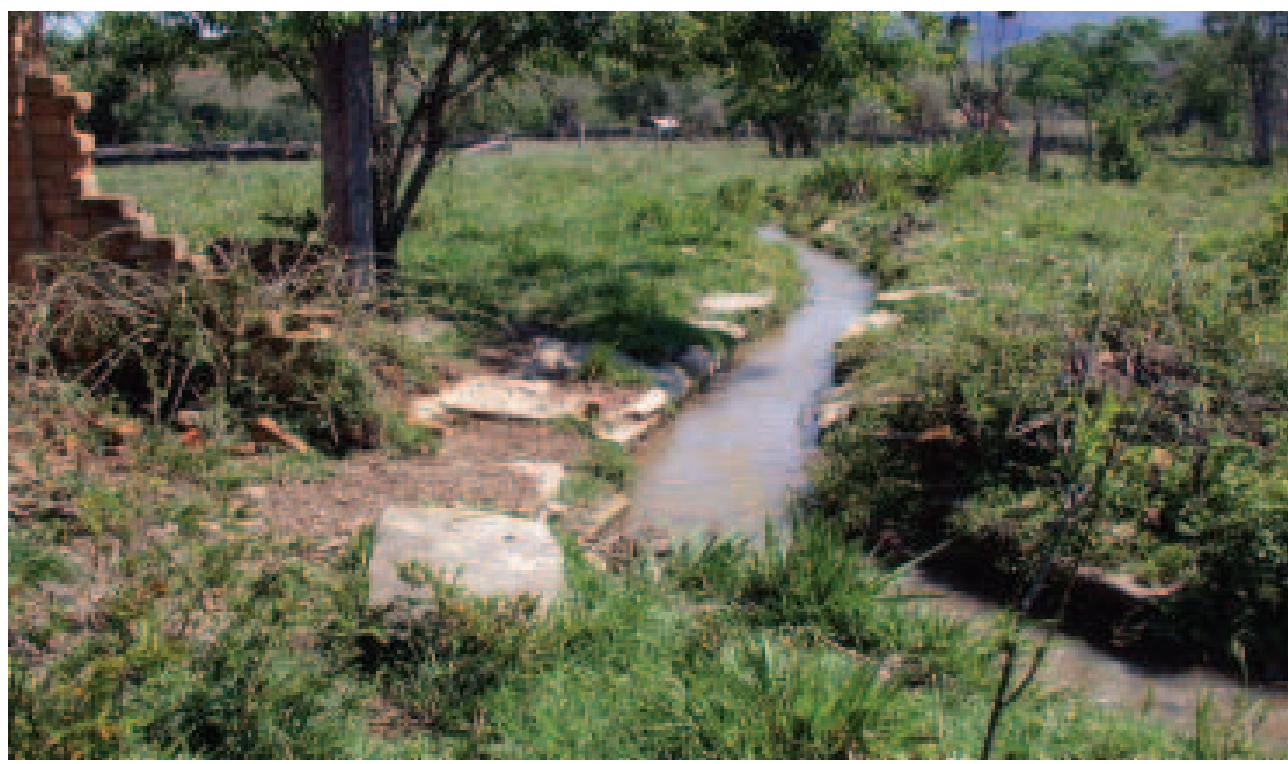

Figura 5 - Curso de água para atender as diversas demandas da fazenda, especialmente para o funcionamento do moinho. Acervo particular do dr. José Américo Junqueira de Mattos. Foto de Verissimo João Dias Neto (Lilo). Nov./2003. 


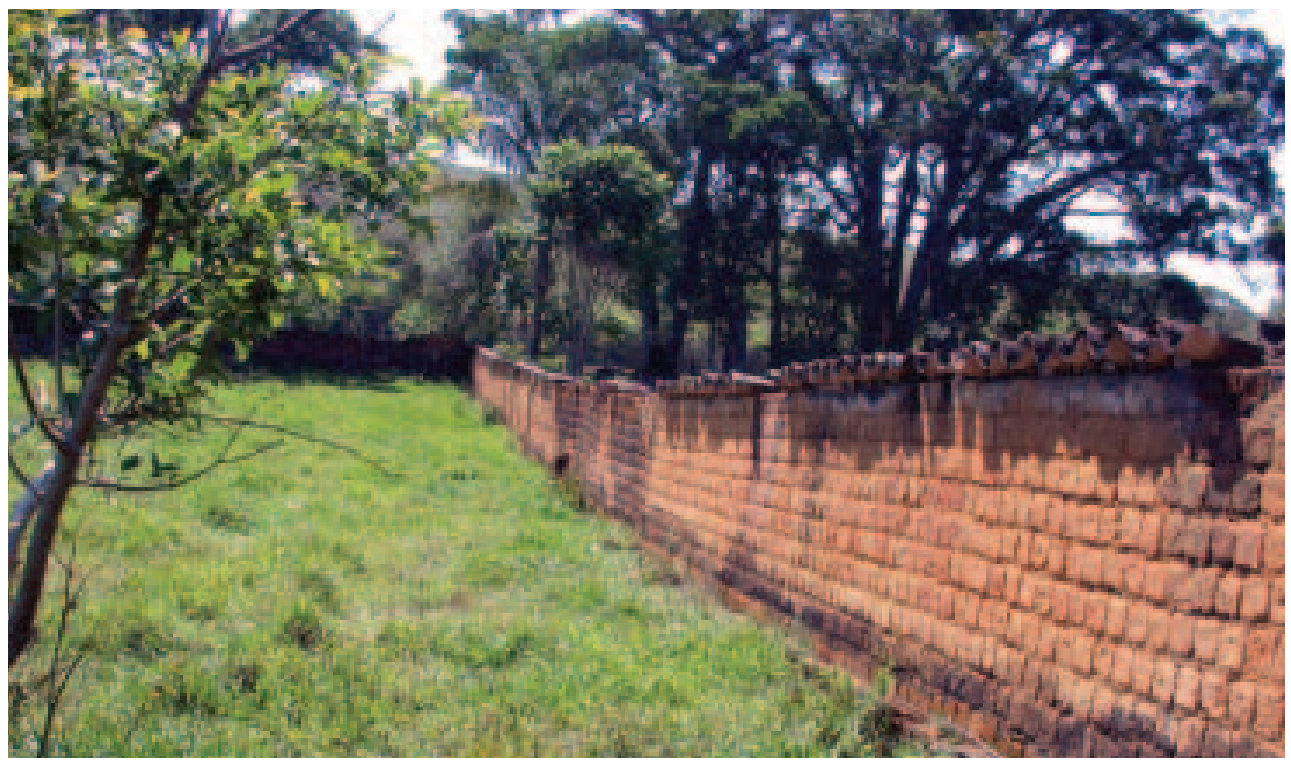

Figura 6 - Detalhe do muro de adobe que cerca parte da fazenda. Acervo particular do dr. José Américo Junqueira de Mattos. Foto de Lilo. Nov./2003.

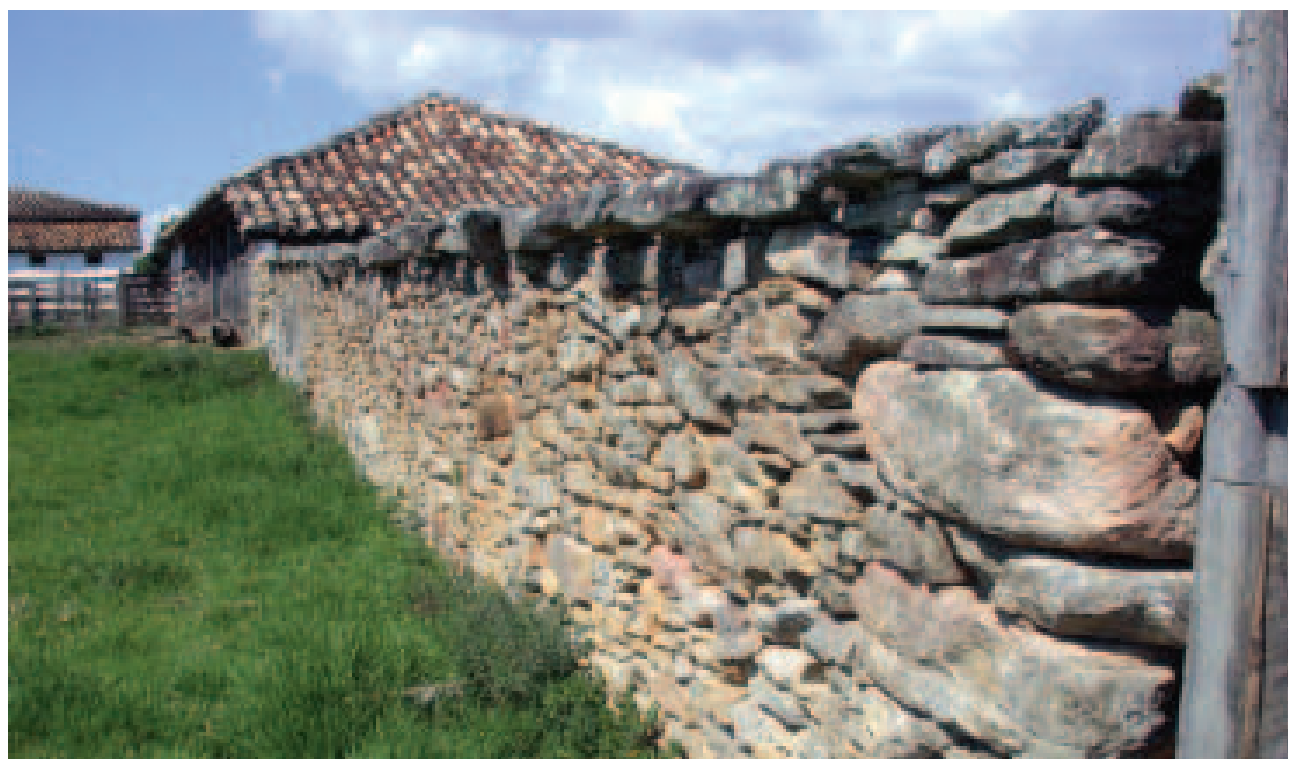

Figura 7 - Detalhe do muro de pedra que divide as partes internas da fazenda lpomar e currais). Acervo particular do dr. José Américo Junqueira de Mattos. Foto de Lilo. Nov./2003. 
4. Os documentos que atestam a construção da sede da Fazenda do Favacho pelo capitão José Vieira de Almeida se encontram reproduzidos na publicação recente de Mattos (2004, p. 40-58). muitas delas são peças extensas e inteiras, atestando uma época em que o artigo era abundante na região (Figuras 8 a 10, Fazendas Boa Vista e Narciso; Figuras 11 e 12, Fazenda Campo Lindo). Poucas benfeitorias como os paióis construídos de madeira e cobertos de telha ainda podem ser vistas em algumas fazendas (Figuras 13 e 14, Fazenda Angaí).

Duas fazendas destoam do padrão discutido até agora e estão relacionadas diretamente à saga da família Junqueira e ao sucesso de seus empreendimentos ligados ao setor abastecedor, muito importante no sul de Minas na primeira metade do século XIX. Embora essas construções também tenham passado por algumas transformações inevitáveis com a ação do tempo, não deixam de atestar a riqueza acumulada pelas primeiras gerações da família, ao longo das primeiras décadas do Oitocentos.

A Fazenda do Favacho foi adquirida pelo patriarca da família, João Francisco Junqueira, de um português chamado José Vieira de Almeida, que requereu sesmaria na região, na segunda metade do século XVIII (AHU, Cons. Ultram, Brasil/MG, cx. 88, doc. 4). Embora a construção não tenha sido feita por João Francisco, essa fazenda é considerada o berço da família Junqueira ${ }^{4} \mathrm{e}$ apresenta sinais claros de que em outros tempos era uma importante unidade escravista com uma arquitetura que causava certa admiração entre os moradores da região. Trata-se de uma construção de um só pavimento, como a maioria das construções rurais mineiras dos séculos XVIII e XIX. O que mais chama a

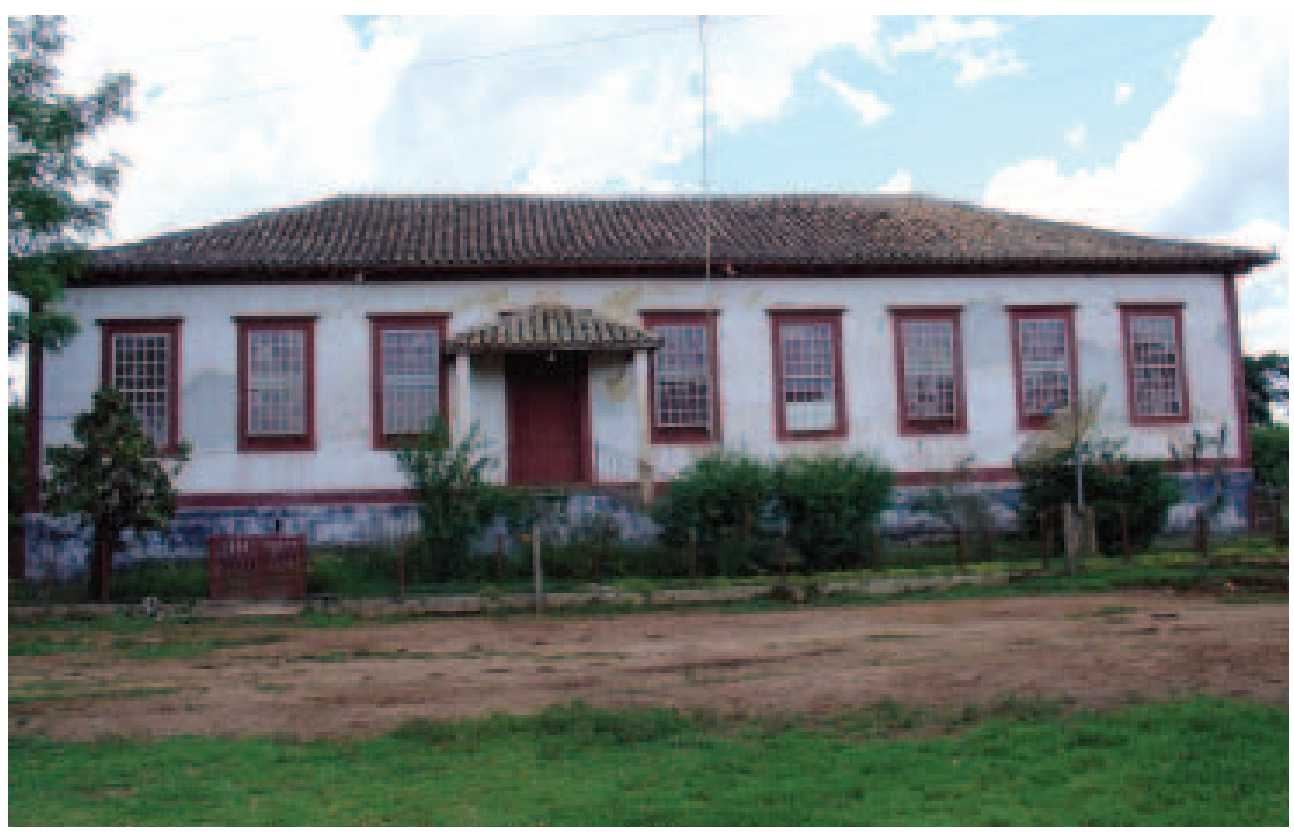

Figura 8 - Fazenda Boa Vista. Acervo particular do autor. Nov./2003. 


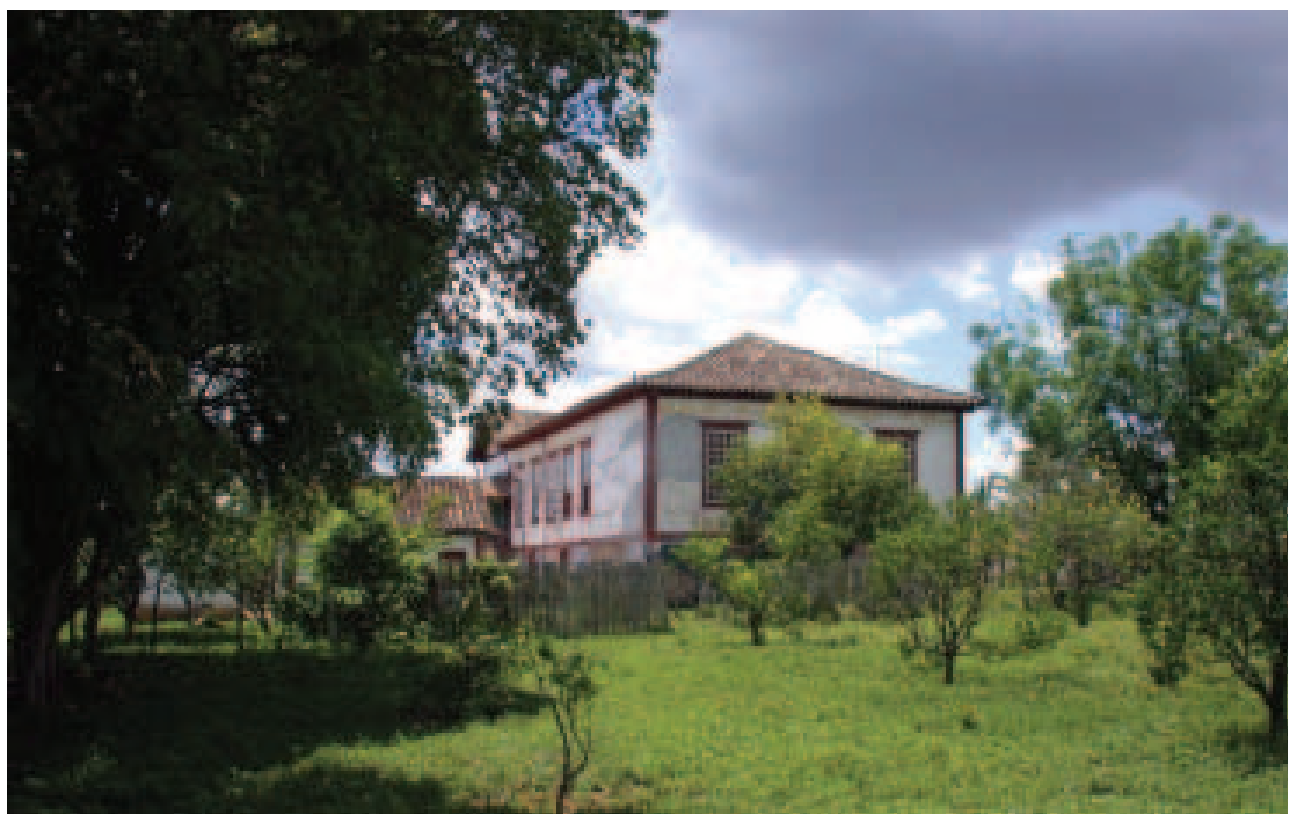

Figura 9 - Vista parcial da sede da Fazenda Boa Vista com destaque para parte do pomar. Acervo particular do dr. José Américo Junqueira de Mattos. Foto de Verissimo João Dias Neto (Lilo). Nov./2003.

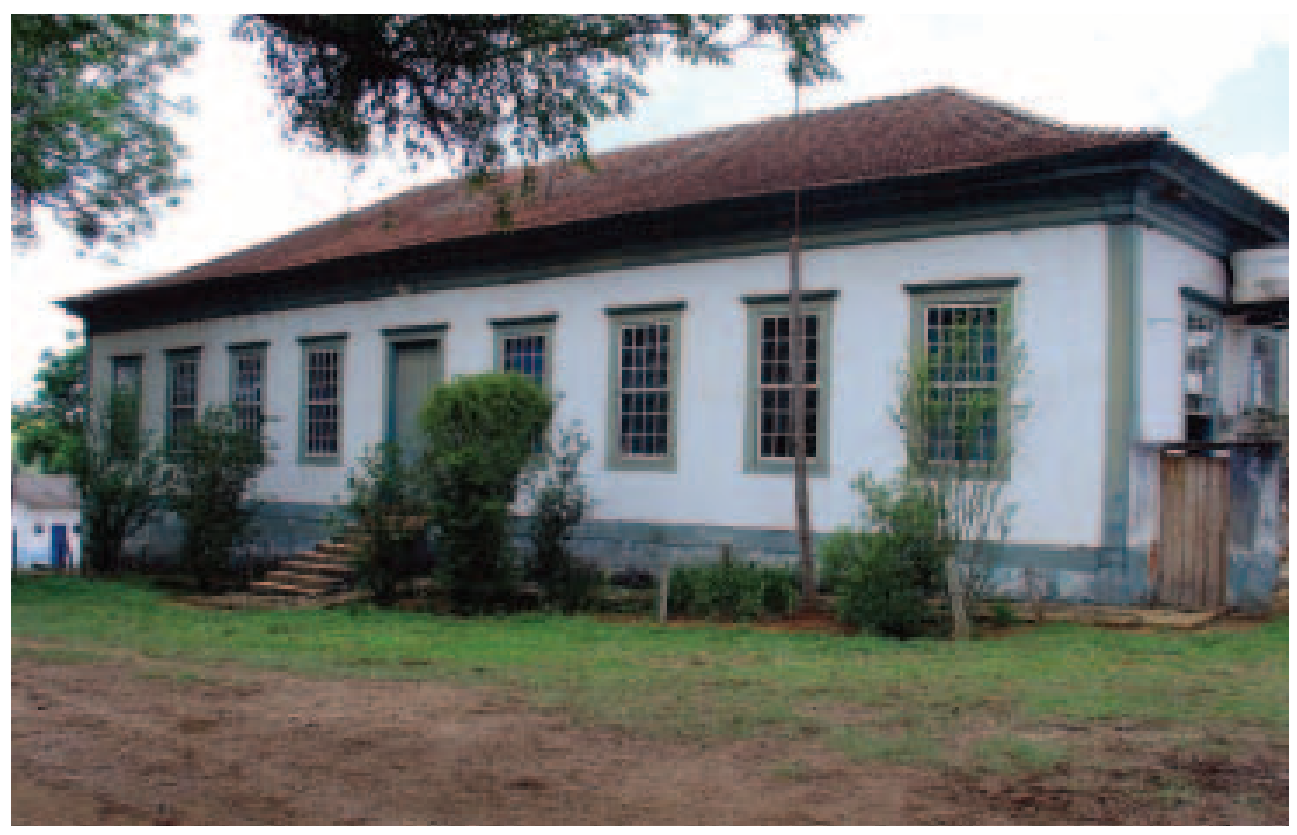

Figura 10 - Fazenda Narciso. Acervo particular do autor. Nov./2003. 


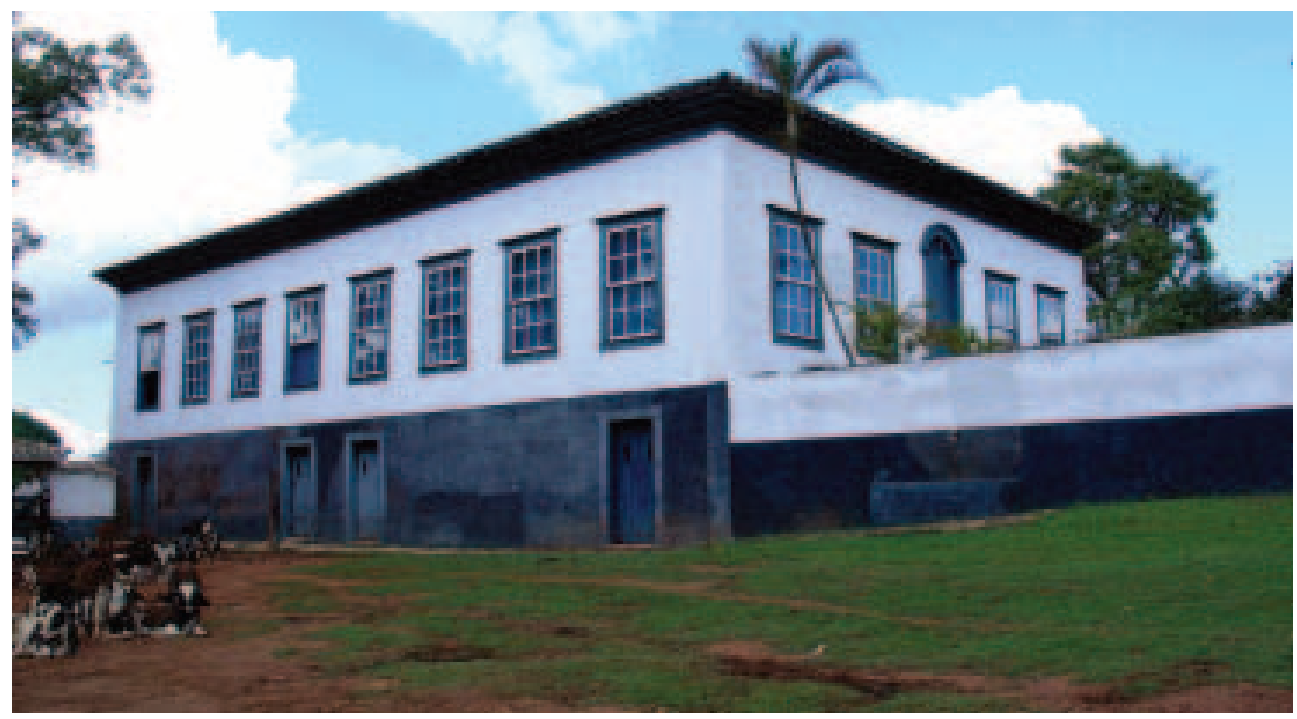

Figura 11 - Vista lateral da Fazenda Campo Lindo. Trata-se de uma segunda sede, construída em 1870. Acervo particular do autor. Nov./2003.

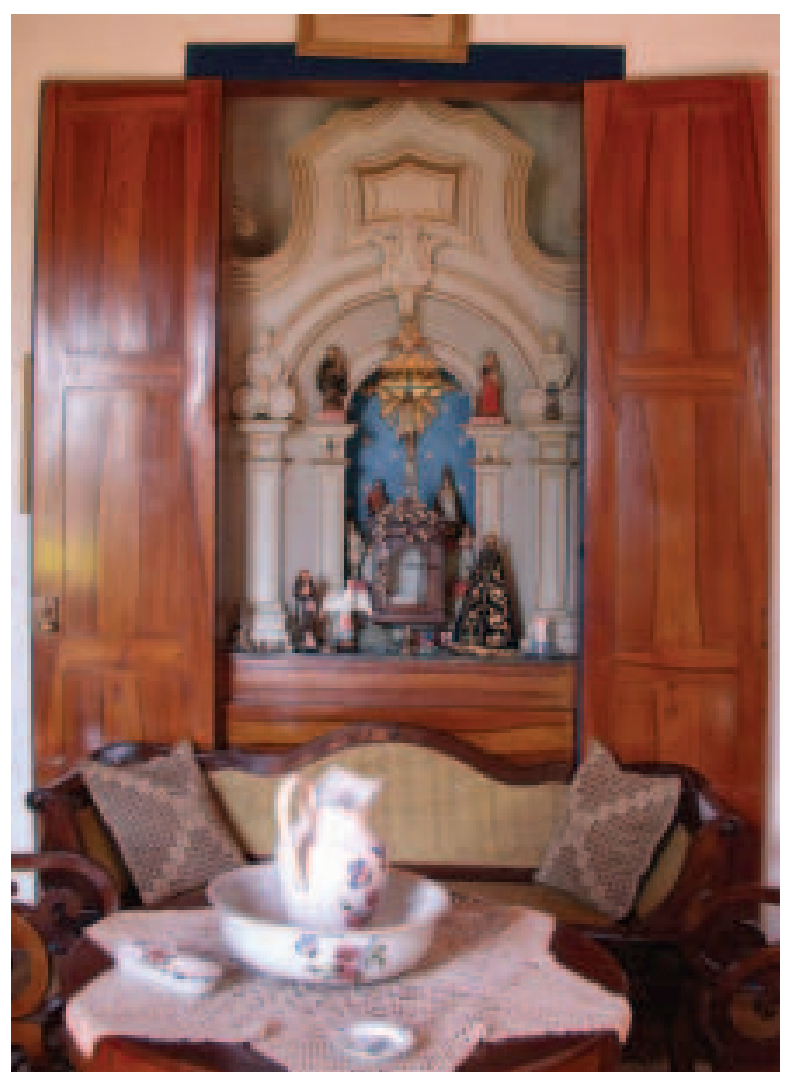

Figura 12 - Grande oratório localizado na sede da Fazenda Campo Lindo. Acervo particular do dr. José Américo Junqueira de Mattos. Foto de Verissimo João Dias Neto (Lilo). Nov./2003. 


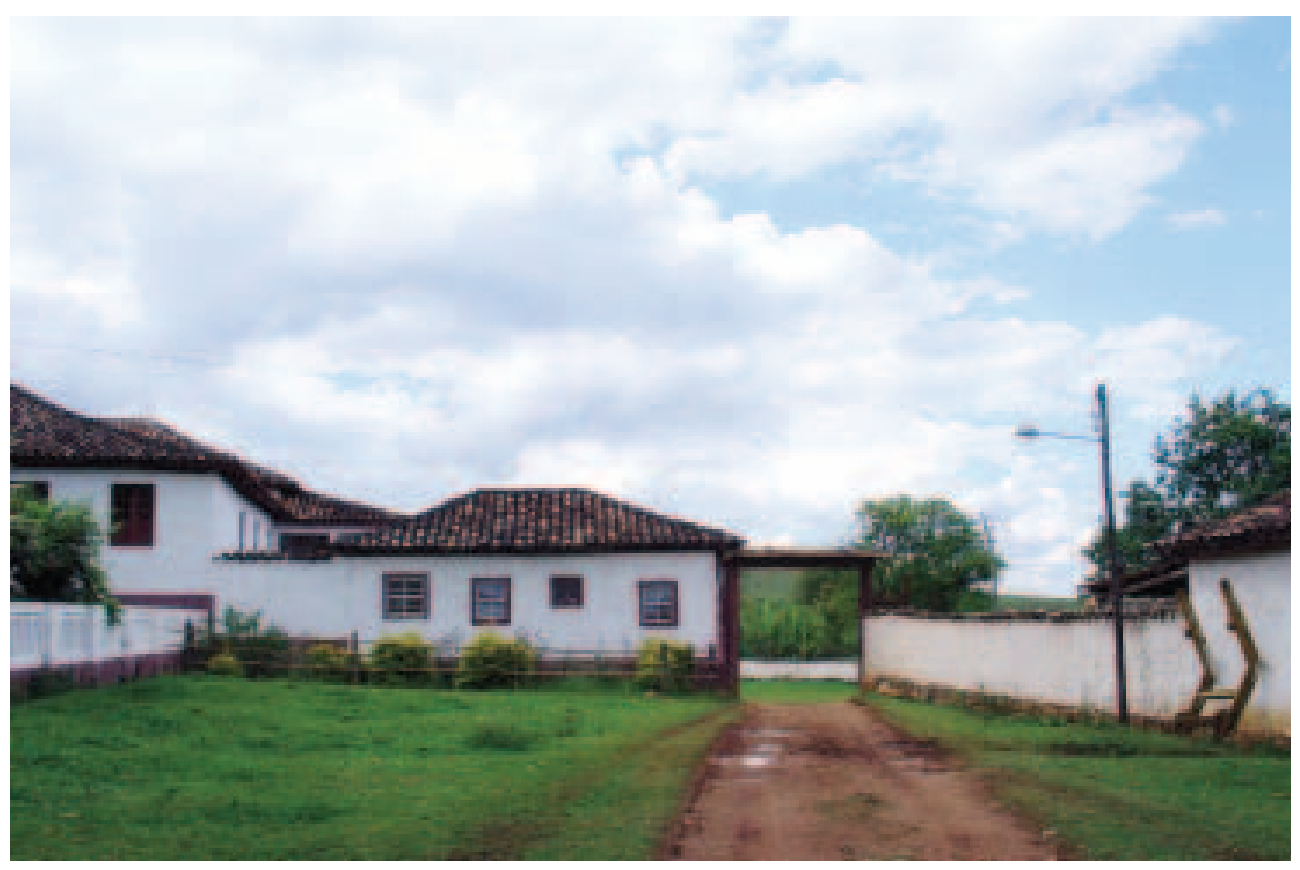

Figura 13 - Vista lateral da Fazenda Angaí. Essa sede sofreu inúmeras transformações e está bastante descaracterizada. Acervo particular do autor. Nov./2003.

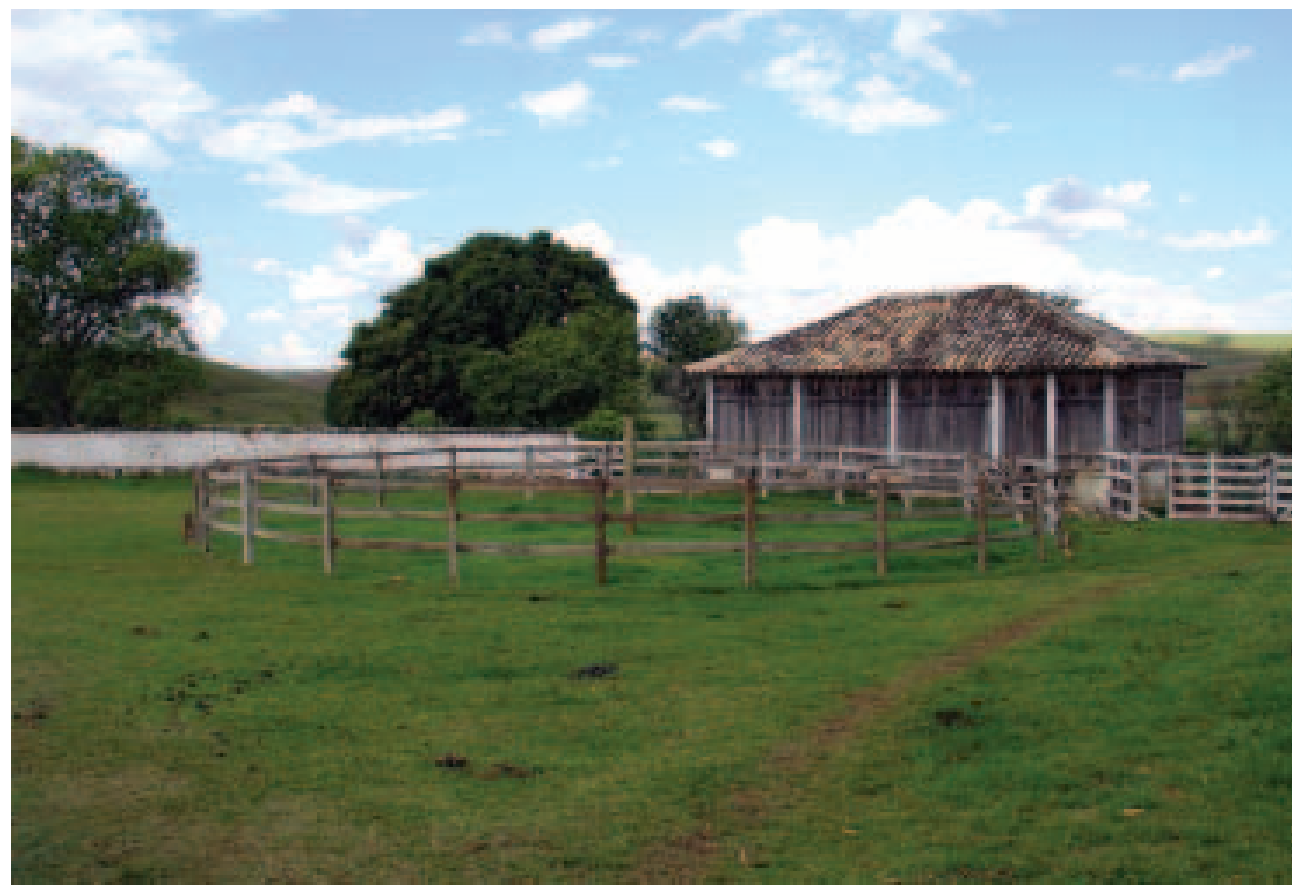

Figura 14 - Fazenda Angaí. Espaço para amansar cavalos e ao fundo pode-se ver um paiol. Acervo particular do autor. Nov./2003. 
5.Trata-se de uma corrup tela da palavra itaituba, que em tupi-guarani quer dizer "pedra-grande". Informação repassada pela atua atenção é a sua estrutura interna e os detalhes dos portais (Figuras 15 a 17). Além da sede da fazenda e das benfeitorias, possuía uma capela em separado, um pouco distante da casa de vivenda, benta em 1761. Lá foram batizados muitos membros da família Junqueira e alguns deles também foram enterrados no cemitério, que fica do lado direito da capela. Logo atrás, localiza-se o cemitério dos escravos (Figuras 18 e 19). Já no inventário realizado em 1826, por ocasião da morte do filho do patriarca da família, João Francisco Junqueira Filho, os avaliadores foram muito econômicos na descrição da propriedade, para tristeza do historiador, relatando somente os valores, sem ao menos mencionar as benfeitorias. A propriedade foi assim descrita: "Mais uma outra parte de terras e casas de vivenda com todos os mais pertences na fazenda Favacho, freguesia de Baependi avaliados em hum conto, quinhentos e setenta mil novecentos e cinqüenta e dois reis" (BASTOS, 1980, p. 94).

A Fazenda da Traituba" surgiu no local denominado "rancho da Traituba", um dinâmico pouso para tropeiros, conhecido e descrito por SaintHilaire (1976), em 1822.

Paramos num imenso rancho, situado em notável posição. Fica rodeado de colinas e dominado por montanha bastante alta, terminada por um tabuleiro cortado a prumo, na face que dá para o rancho. Depois de nós, várias caravanas vieram sucessivamente aboletarse no rancho. Vêm umas do Rio de Janeiro para S. João e Barbacena, carregando sal; vão outras destes arredores para a capital e levam toucinho e queijos (SAINT-HILAIRE, 1976, p. 48-49).

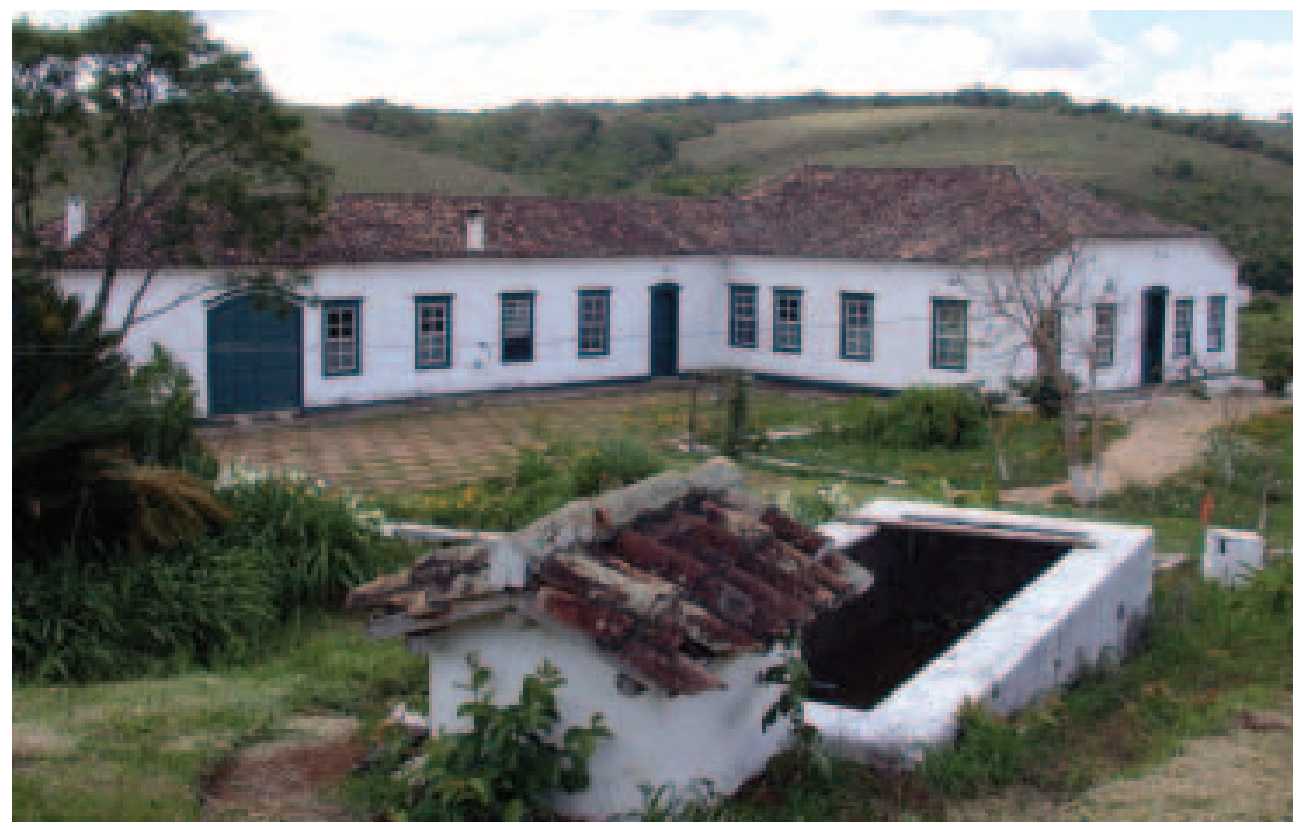

Figura 15 - Vista frontal da Fazenda do Favacho. Acervo particular do dr. José Américo Junqueira de Mattos. Foto de Verissimo João Dias Neto (Lilo). Nov./2003. 


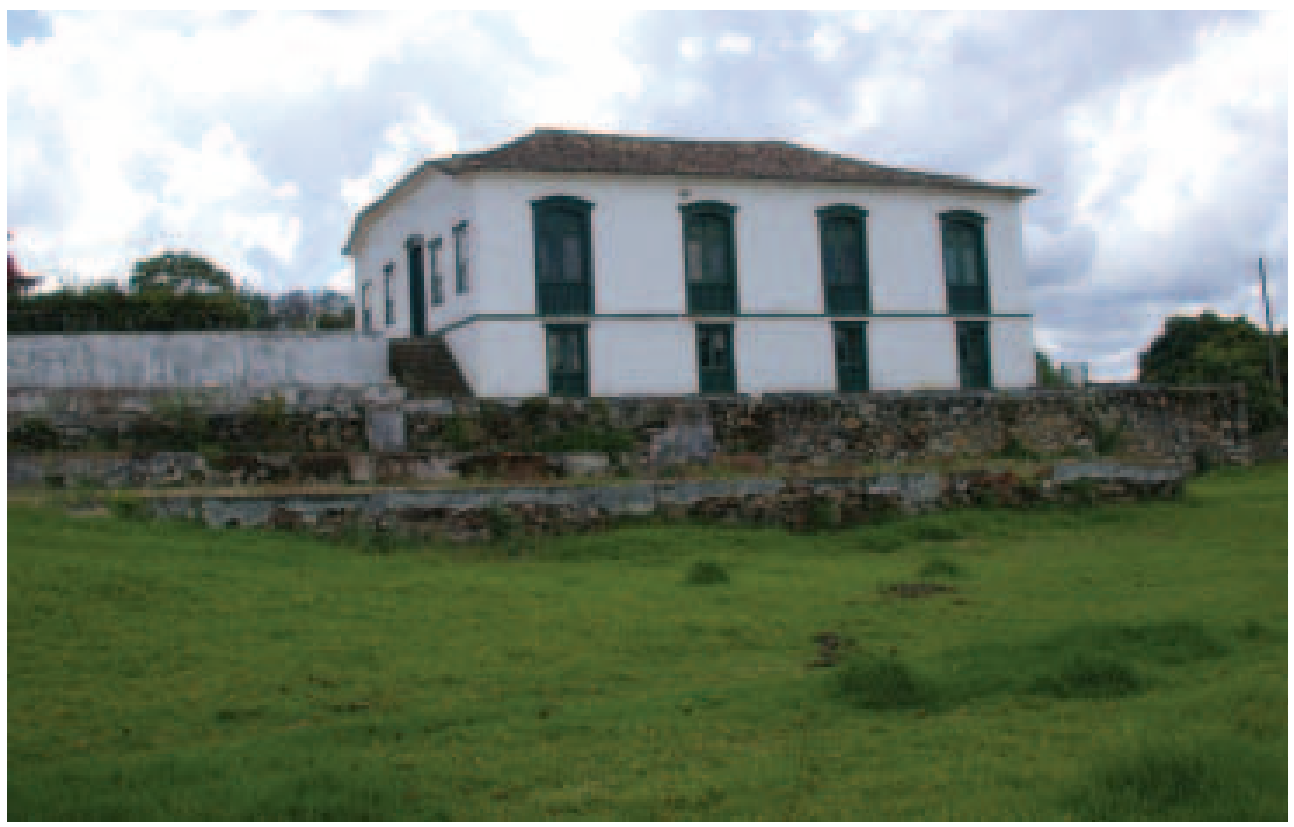

Figura 16 - Vista lateral da Fazenda do Favacho. Acervo particular do dr. José Américo Junqueira de Mattos. Foto de Verissimo João Dias Neto (Lilo). Nov./2003.

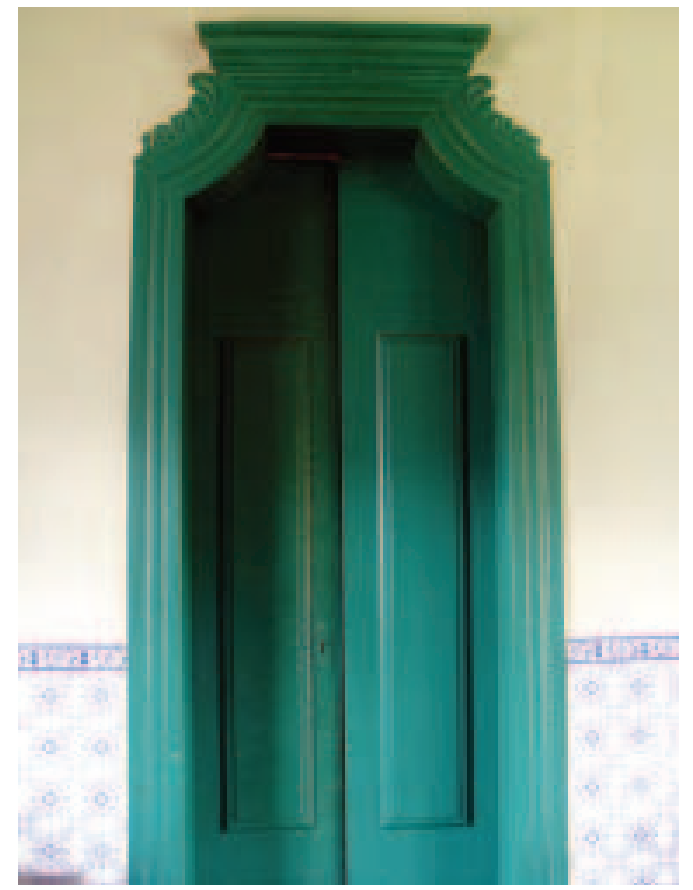

Figura 17 - Detalhe do portal do interior da Fazenda do Favacho. Acervo particular do autor. Nov./2003. 


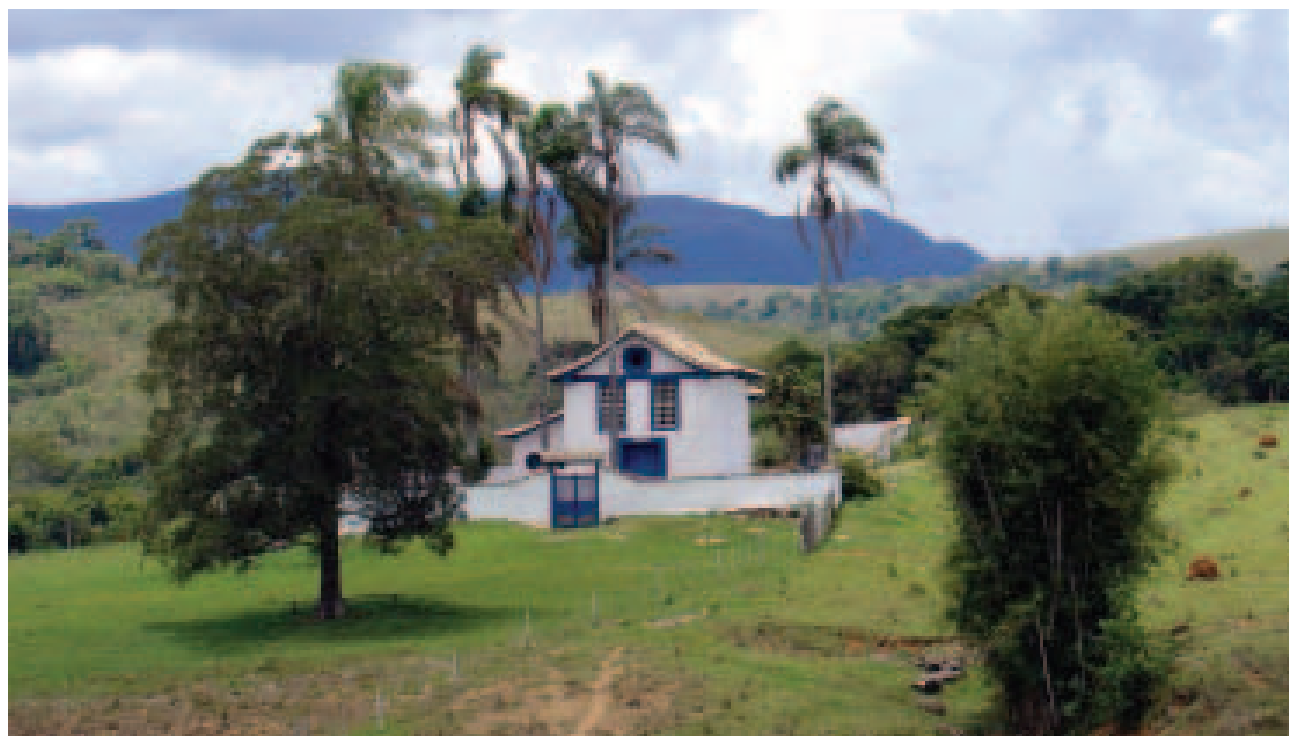

Figura 18 - Capela de São José do Favacho, benta em 1/1/1761. Acervo particular do autor. Nov./2003.

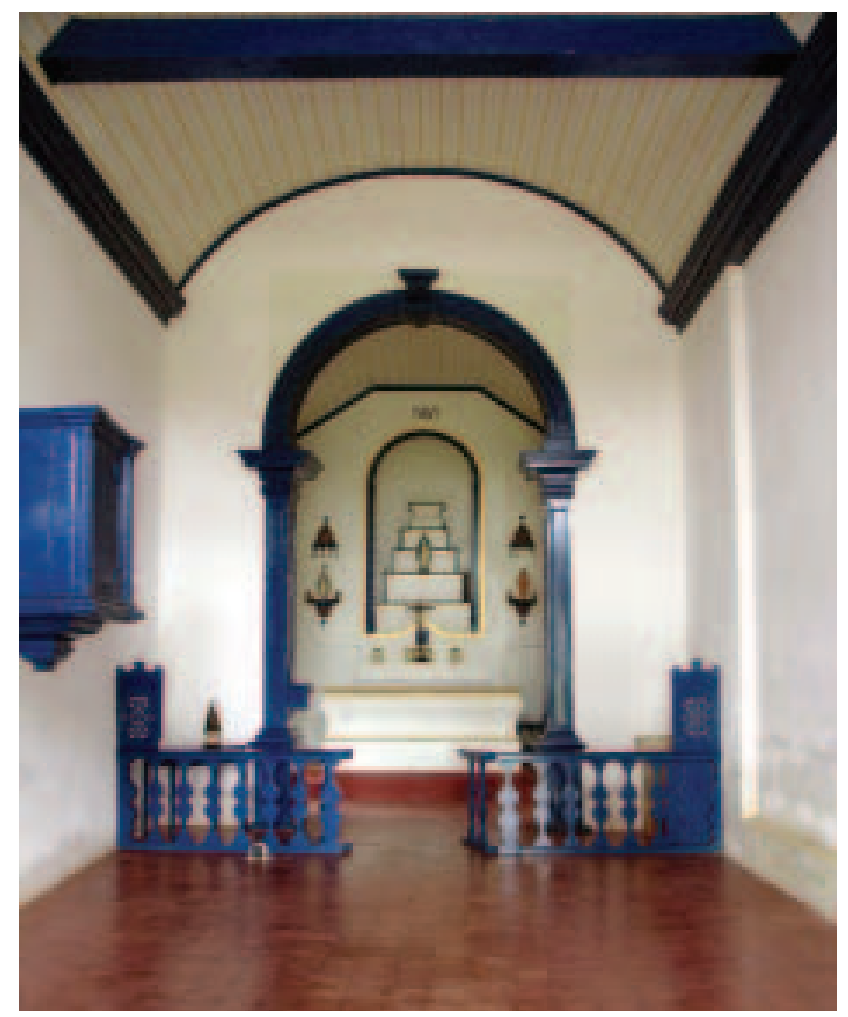

Figura 19 - Interior da Capela de São José do Favacho. Por causa da ação do tempo, algumas intervenções foram necessárias. A capela foi restaurada em março de 2002. Acervo particular do autor. Nov./2003. 
No final da década de 1830, esse rancho transformou-se na imponente Fazenda da Traituba, construída pelo coronel João Pedro Diniz Junqueira, sobrinho do deputado Gabriel Francisco Junqueira. Tratava-se de uma construção arrojada para os padrões da época e, especialmente, para uma sede ligada à atividade agropastoril e ao abastecimento interno. Segundo a tradição familiar, a sede era composta de dois pavimentos mais um mirante e fora construída para receber o imperador D. Pedro l, que nunca veio, pois tão logo a sede da fazenda ficou pronta, o monarca abdicou do trono. Também se comenta que o proprietário ficara bastante endividado pelo que gastou na construção da sede (BRIOSCHI, 1985, p. 197; BROTERO, 1959; MATTOS, 2004).

Essa fazenda já foi objeto de investigação no que se refere à sua estrutura arquitetônica e às mudanças que ocorreram ao longo do tempo. Nicoliello e Carvalho (1985) constataram, por meio de vestígios detectados no barroteamento que ainda se conserva na estrutura da sede atual, indícios de que havia um segundo pavimento e um mirante 6 . Segundo os autores, a construção apresenta uma característica única na arquitetura rural da região, pois não havia "nenhum enxerto de puxados anexos nos fundos da construção". Tudo fazia parte de um só bloco, separado por alas: no retângulo maior ficava a ala social; no retângulo menor $A$, a cozinha e a despensa e no retângulo menor $B$, a suposta tecelagem e os aposentos para os escravos domésticos (Figuras 20 a 22). 0 pavimento térreo compunha-se de 17 quartos e cinco salas. $O$ pavimento superior

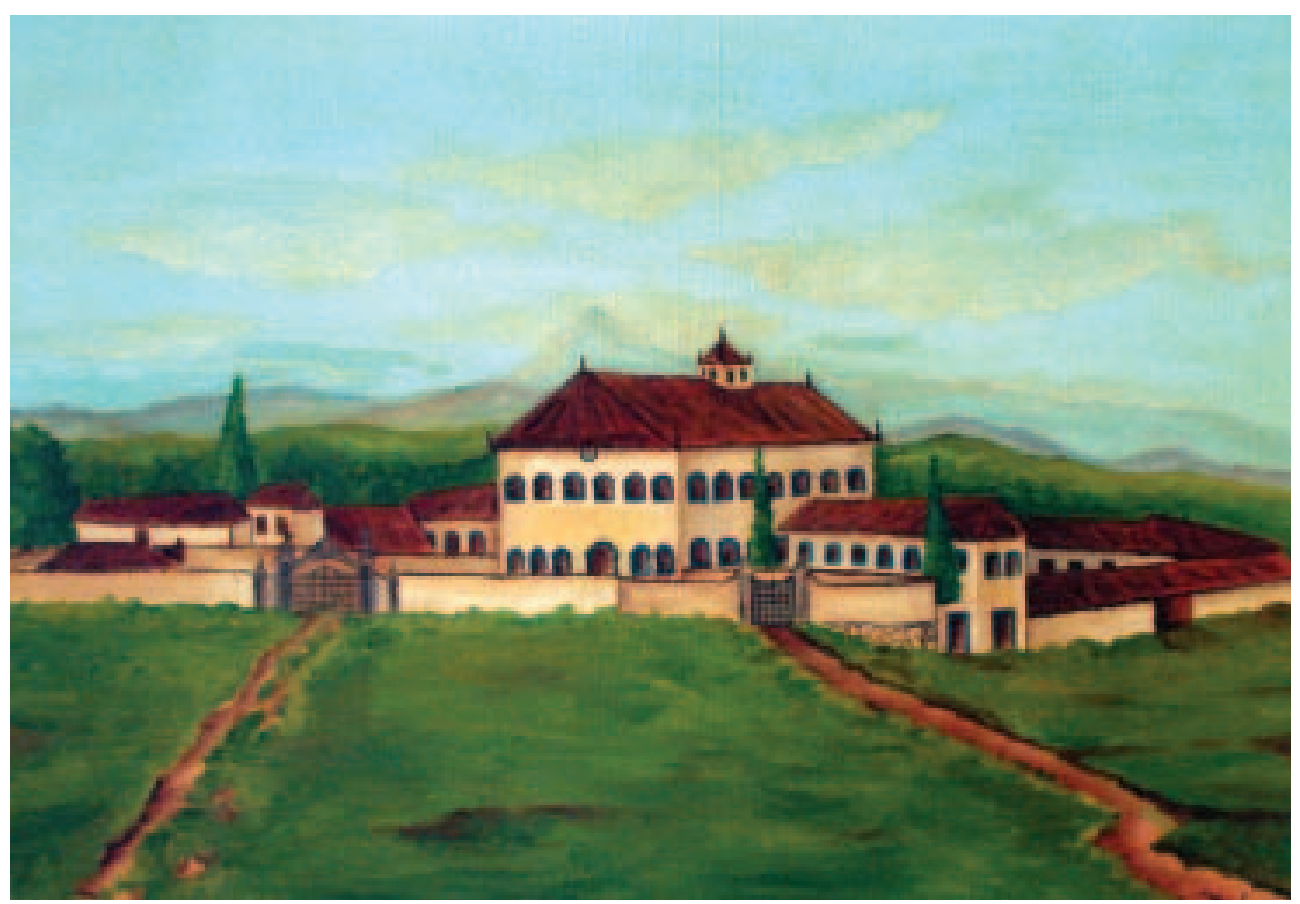

Figura 20 - Pintura da Fazenda da Traituba com base na foto mais antiga. Observa-se que a sede antiga era constituída de dois pavimentos, mais um mirante no meio. Acervo particular do dr. José Américo Junqueira de Mattos. Foto de Verissimo João Dias Neto (Lilo). Nov./2003.
6. Há um outro estudo arquitetônico mais recente sobre a fazenda, embora não acrescente novas informações do ponto de vista histórico. Cf. HERING et. al., 1994. 


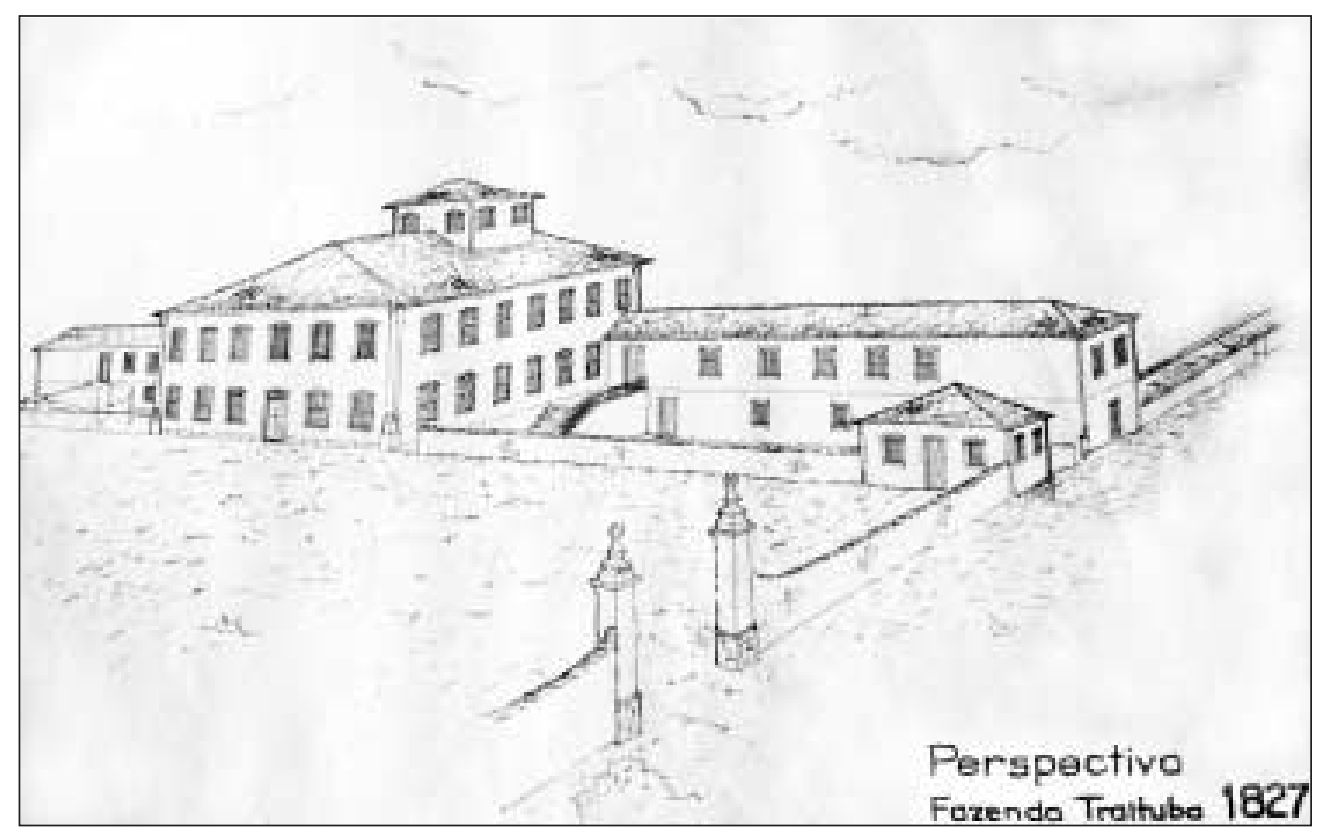

Figura 21 - Perspectiva da fazenda na sua configuração original. Estima-se que a construção da antiga sede teve início em 1827 e foi concluída no ano de 1831. (NICOLIELLO; CARVALHO, 1985).

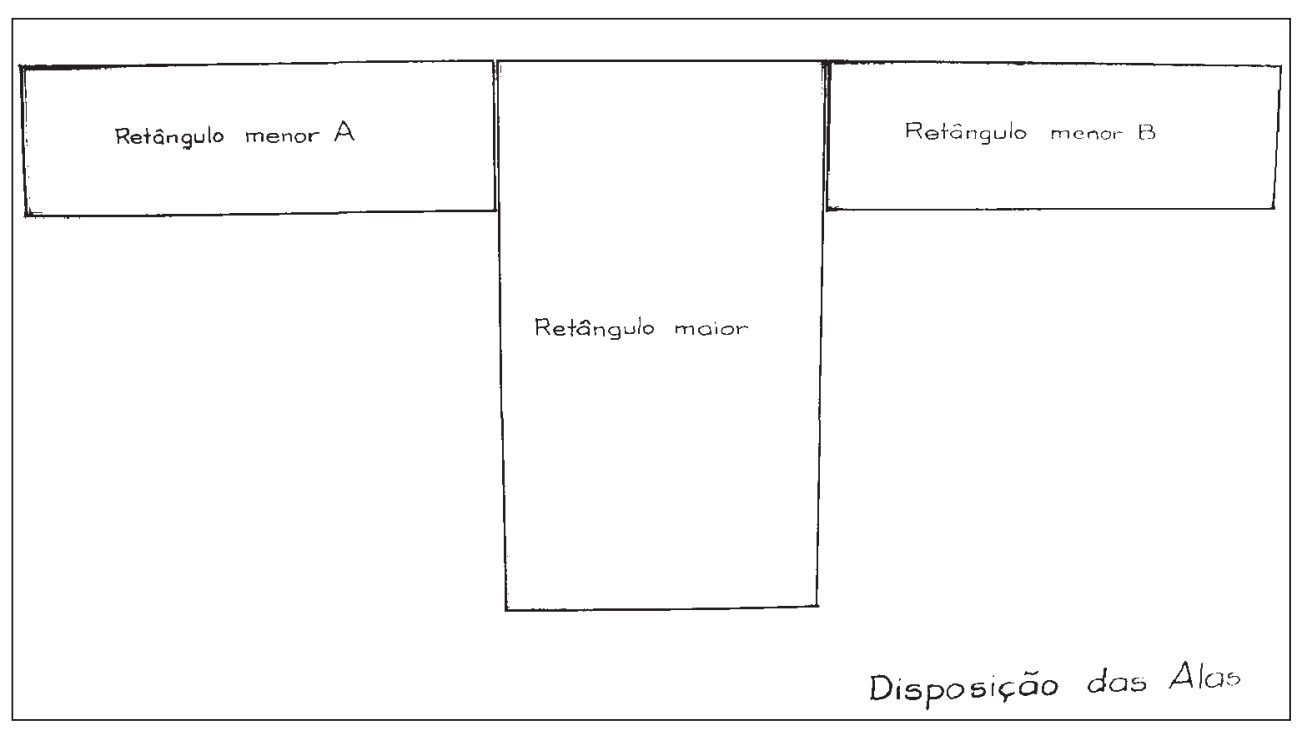

Figura 22 - Disposição das alas. Retângulo menor A: cozinhas, fornos e despensa. Retângulo maior: ala social. Retângulo menor B: suposta tecelagem e aposento para escravos domésticos. (NICOLIELLO; CARVALHO, 1985). 
possuía oito quartos e mais duas salas amplas. Em 1902, a sede da fazenda passou por uma reforma radical, sendo demolido o mirante e o segundo pavimento. "O telhado, antes de quatro águas, recebe configuração eclética, em moda na Europa; os chalés de duas águas passam a ser ornados com lambrequins de madeira." Essa alteração se deu no retângulo maior, pois somente ele possuía dois pavimentos, os outros dois continuaram com quatro águas. A senzala foi demolida na década de 1940 (NICOLIELLO; CARVALHO, 1985, p. 15).

Considerando todas as transformações, a sede da fazenda ainda impressiona a todos os visitantes que por lá passam e pernoitam (Figuras 23 a 25). A atual sede ainda possui 14 quartos, duas cozinhas, sete salas, duas despensas, um escritório, seis banheiros, jardins, etc. Dando continuidade à tradição dos tempos de outrora, a fazenda continua servindo de pouso, só que agora para os "tropeiros" modernos que procuram descansar, relembrar alguma reminiscência de infância na roça e entrar em contato com algumas marcas do tempo da escravidão.

Os indícios da opulência de parte das famílias de elite do sul de Minas ainda podem ser vistos nos belos portais heráldicos da Fazenda Traituba, ricamente trabalhados em pedra-sabão. São dois laterais e um frontal. O mais imponente é o que dá acesso principal pela parte frontal da fazenda. Depois de cruzar o portal, é só o viajante olhar para trás e ver cravado no marco central a data de finalização da construção da fazenda, Ano de Nosso Senhor Jesus

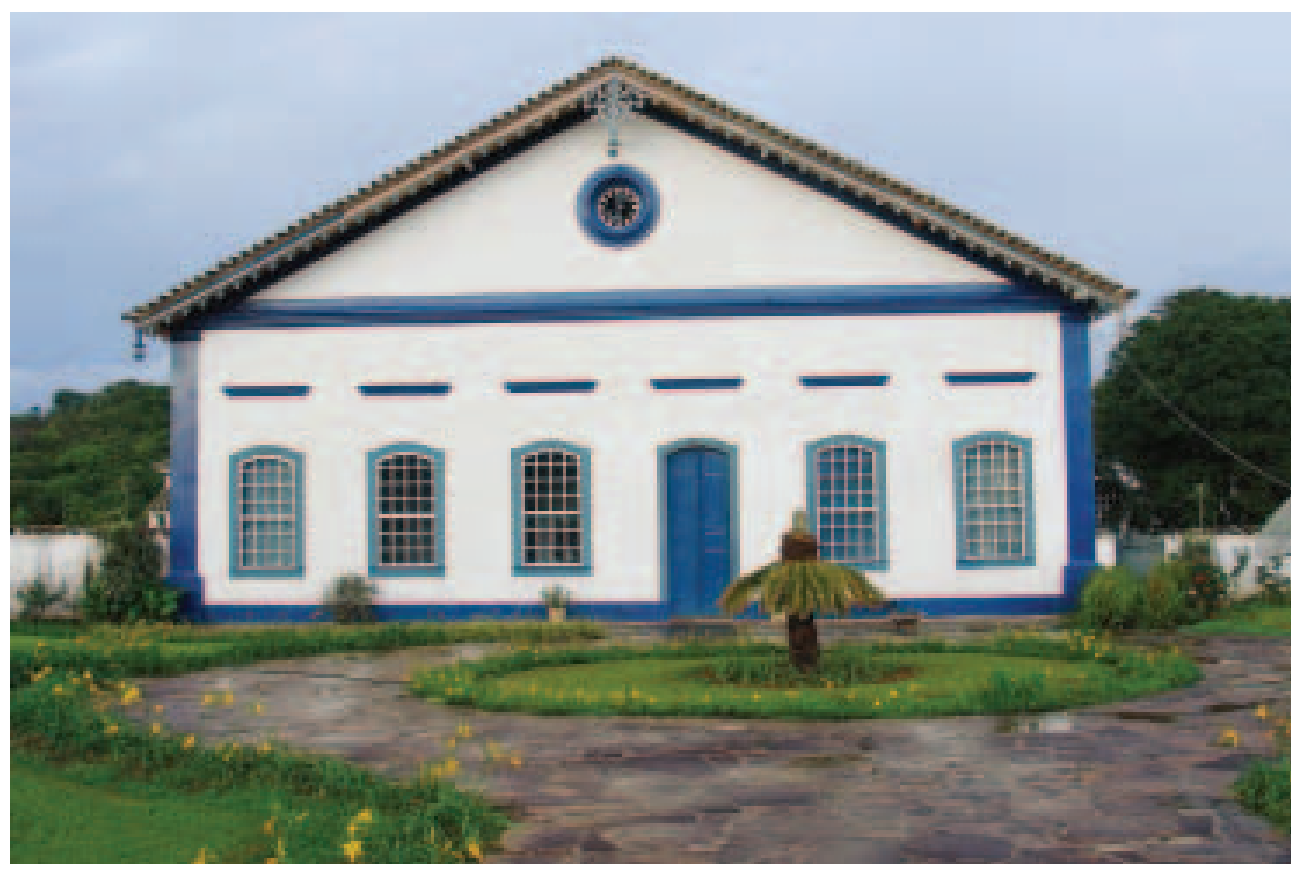

Figura 23 - Vista frontal da sede atual da Fazenda Traituba. Acervo particular do autor. Nov./2003. 


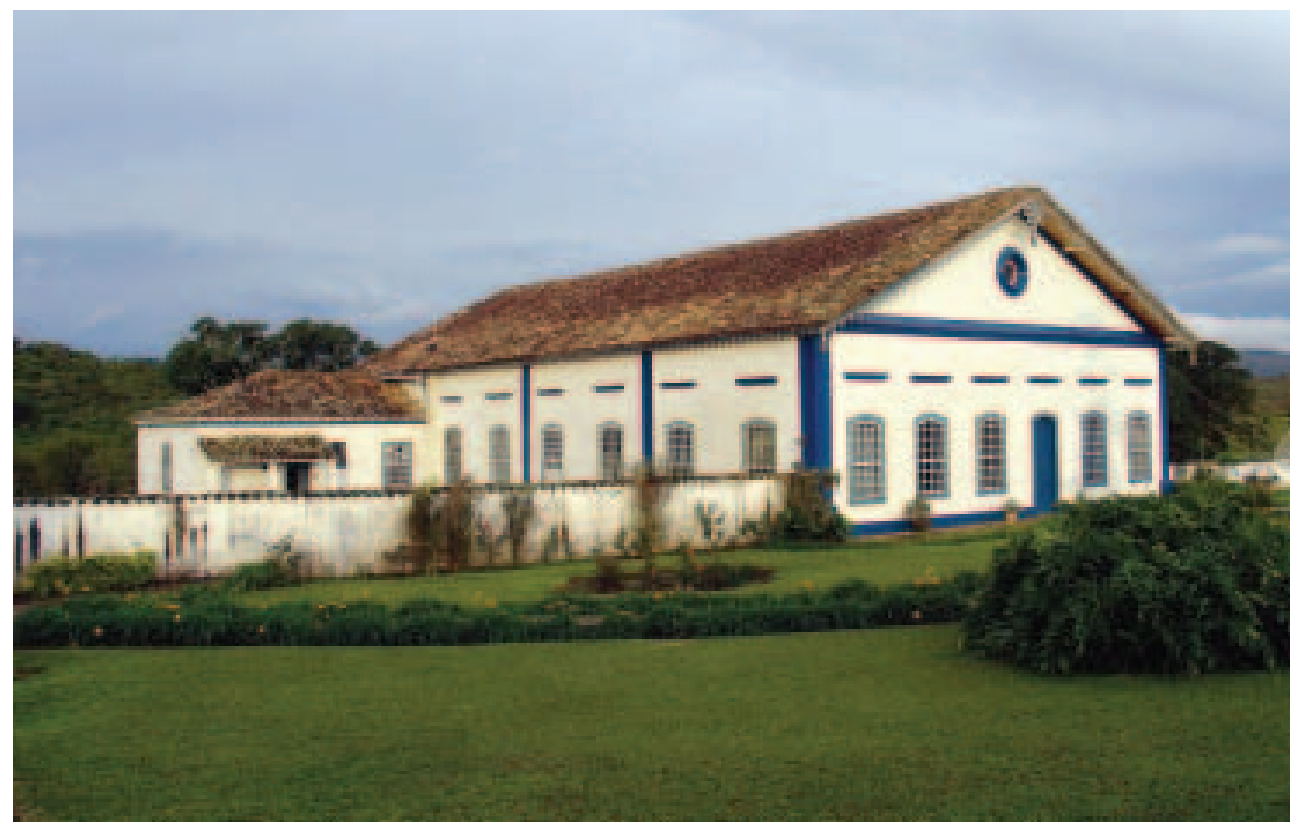

Figura 24 - Vista lateral da fazenda. Acervo particular do autor. Nov./2003.

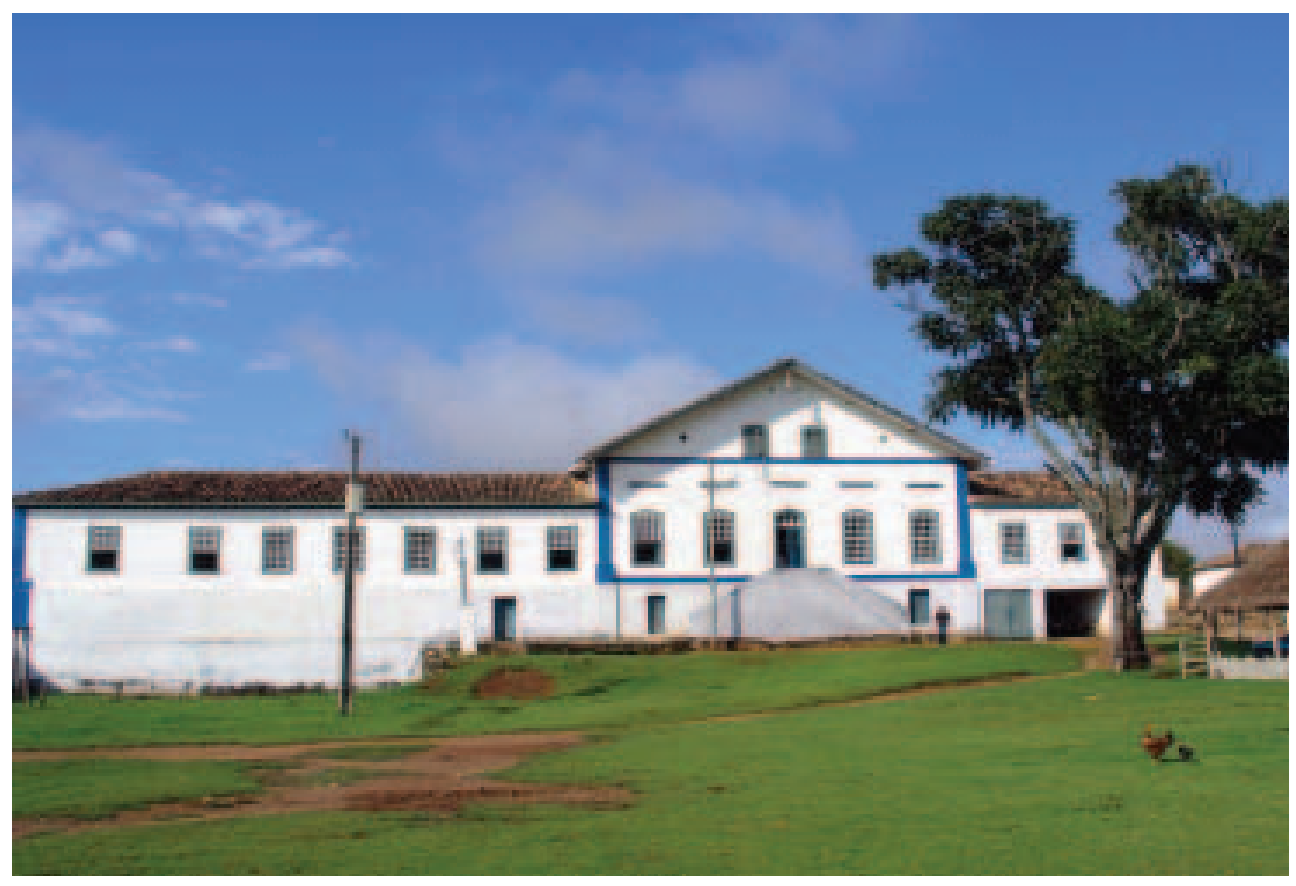

Figura 25 - Vista parcial da fazenda, pelos fundos. Acervo particular do autor. Nov./2003. 
Cristo, 1831 (Figuras 26 a 28). O extenso gramado que separa o portal da entrada da sede servia em outros tempos de pouso para tropeiros, e muitos negócios ali foram realizados, garantindo a riqueza de muitos proprietários e negociantes. Além de hotel-fazenda, os descendentes da família continuam criando gado leiteiro e o cavalo manga-larga marchador, mantendo parte da tradição secular dos Junqueiras.

Adentremos agora no espaço íntimo da casa dos grandes senhores rurais sul-mineiros, vasculhando o interior de suas moradas em busca de maiores informações e detalhes sobre o seu estilo de vida. Saint-Hilaire (1976) descreve a simplicidade dos interiores das casas e até mesmo a falta de conforto em muitas das "casas de vivenda" das fazendas mineiras, nas quais costumava pedir pouso. Geralmente o mobiliário da sala estava reduzido a uma mesa, bancos e porta-chapéus.

A sala é a primeira peça que se encontra ao entrar, e seu mobiliário consiste unicamente de uma mesa, um par de bancos e uma ou duas camas desarmadas. Dificilmente deixará de haver, distribuídos ao redor da sala, vários porta-chapéus, onde se penduram também as selas, rédeas, chicotes, etc. (SAINT-HILAIRE, 1976, p. 56).

autor confirma a rusticidade das construções e do interior das casas dos mineiros mais abastados ao pernoitar em uma fazenda de um grande negociante de gado, que possuía uma riqueza conhecida por todos e um modo de vida e uma casa que impressionavam os habitantes da região.

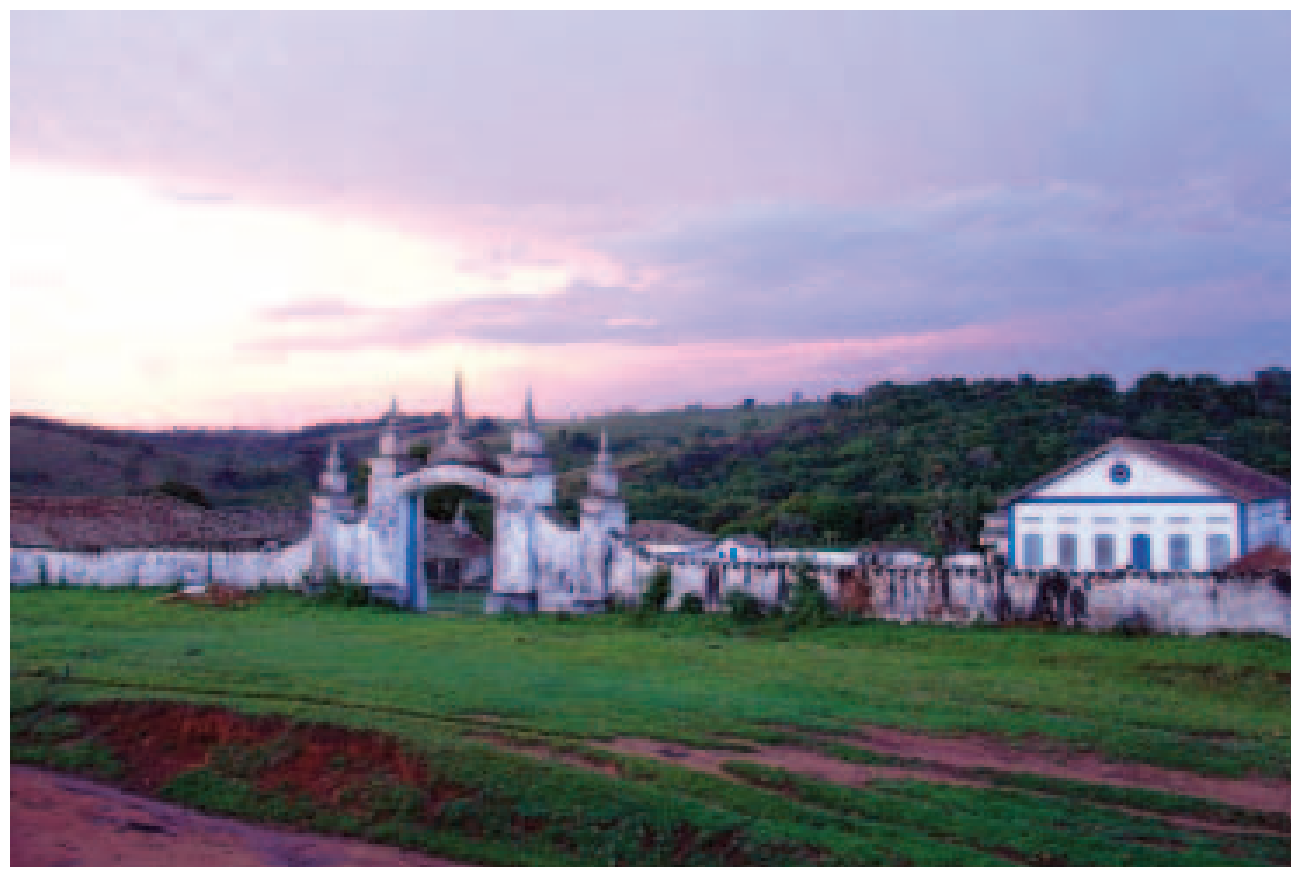

Figura 26 - Portal heráldico que circunda a sede da fazenda. Acervo particular do autor. Nov./2003.

Annals of Museu Paulista.v. 12. Jan.-Dec. 2004. 


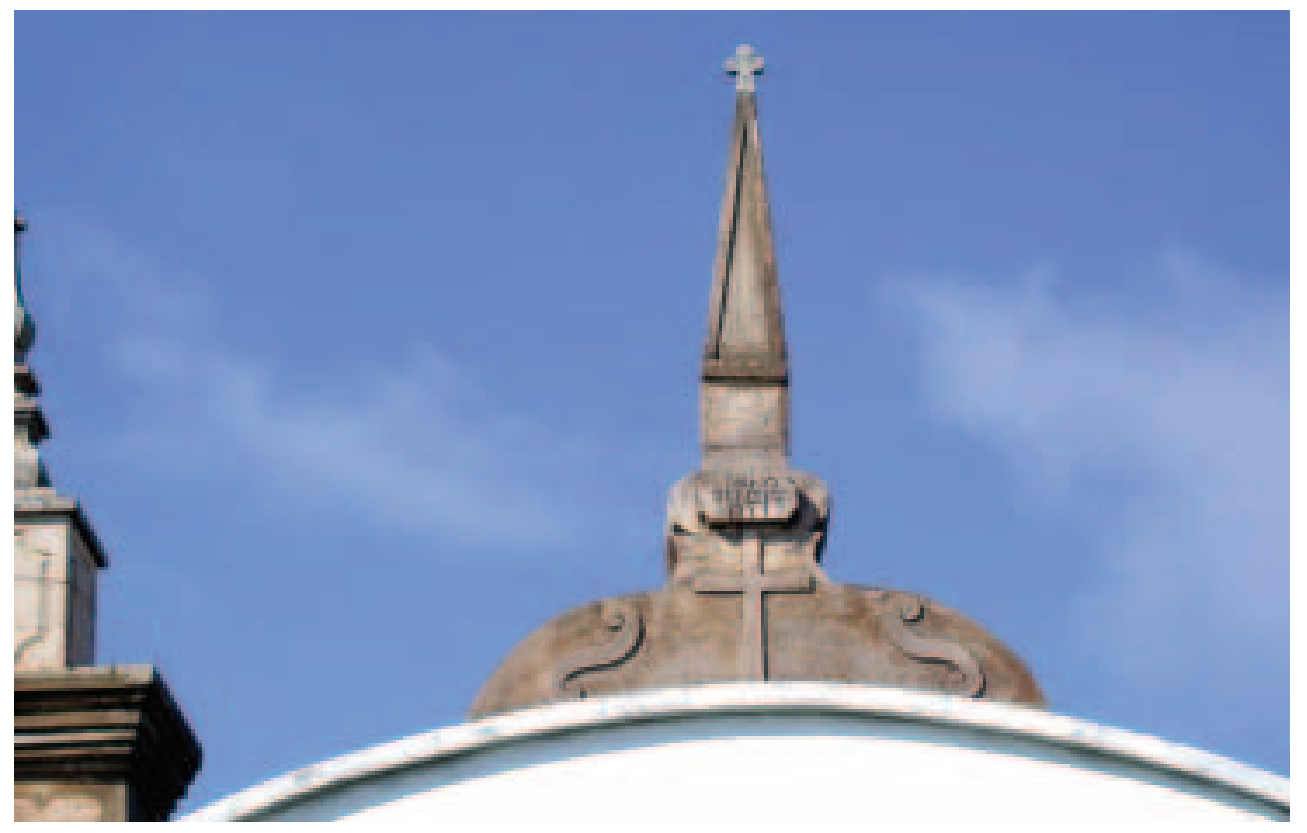

Figura 27 - Detalhe do portal heráldico da entrada, de pedra-sabão, onde se pode constatar a referência: "Anno de N. S. J. C. 1831 ", data de finalização da construção da sede da fazenda. Acervo particular do dr. José Américo Junqueira de Mattos. Foto de Verissimo João Dias Neto (Lilo). Nov./2003.

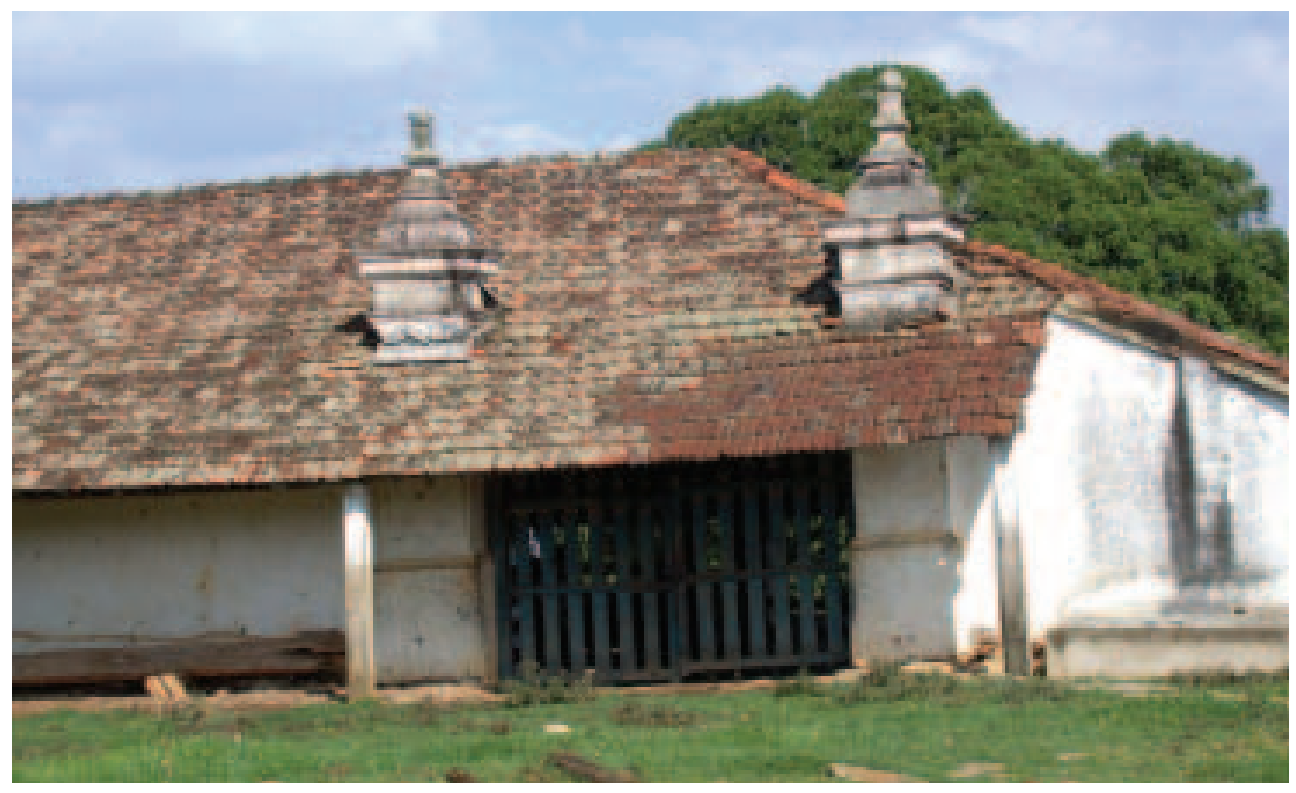

Figura 28 - Parte do atual curral da fazenda e destaque para a parte do antigo portal lateral que não foi destruído. Os dois portões laterais ainda apresentam, no seu topo, globos terrestres com os trópicos e detalhes do brasão imperial. Acervo particular do dr. José Américo Junqueira de Mattos. Foto de Verissimo João Dias Neto (Lilo). Nov./2003. 
Sua casa, entretanto, que ele mesmo mandou construir, era pequena, baixa e de um só pavimento. As paredes, feitas de barro, nunca tinham sido caiadas, e todo o mobiliário da sala consistia numa mesa grande, dois bancos e alguns tamboretes forrados de couro. Dois ou três quartos pequenos, que pude entrever e davam para a sala, mostravam os móveis igualmente modestos. Entretanto, o meu tropeiro fazia grandes elogios a essa casa, o que vem provar de maneira clara que o luxo não tinha feito grandes progressos nessa parte da Província. Não quero deixar de mencionar a entrada do pátio da fazenda que é construída simplesmente de uma porteira, semelhante às que são usadas para fechar pastos. São feitas com duas vigas verticais e algumas tábuas horizontais, separadas umas das outras (SAINTHILAIRE, 1976, p. 56).

Em outra passagem, o autor comenta sobre uma fazenda em que o dono não se encontrava presente. Os escravos do proprietário permitiram que ele e seus acompanhantes se estabelecessem sob a varanda da sede da fazenda até o entardecer. Assim que anoiteceu, tiveram acesso à sala para que ali dormissem. Novamente o autor descreveu a simplicidade do interior das fazendas mineiras, resumida a alguns bancos, camas e mesas e também ao costume de se pregar várias cruzes de madeira nas paredes.

Tive, por conseguinte, ocasião de ver o interior e achei-o igual ao da maioria das habitações desta comarca, quer dizer, quase nu. Na sala, apenas uma mesa e um banco, e nos quartos duas armações de camas de madeira. Nas paredes da varanda e sala está pregada uma série de cruzes de pau, de diferentes dimensões, costume observado em todas as casas antigas (SAINTTHILAIRE, 1976).

Em que medida as informações de Saint-Hilaire fazem sentido e em que aspectos podem ser relativizadas? $\bigcirc$ caminho mais natural para a busca dessa resposta está na análise detalhada dos bens existentes no interior das casas de vivenda e de morada da elite escravista sul-mineira, que mereceram registro nos inventários.

A primeira metade do século XIX foi marcada por profundas transformações na história do Império brasileiro. Logo na primeira década, a chegada da Corte não modificou de imediato o estatuto colonial, mas promoveu mudanças importantes na ordem sociopolítica, econômica e também cultural, com a implantação e reprodução de várias instituições portuguesas nos trópicos (DIAS, 1972; LENHARO, 1979; NEVES, 1999). Novos hábitos e costumes puderam, aos poucos, ser percebidos, tanto na forma de se construir quanto de mobiliar as residências, de se vestir, de se alimentar, etc. $\bigcirc$ consumo de bens industrializados ingleses e a influência francesa se fizeram presentes na Corte e foram, em parte, reproduzidos nas vilas e fazendas do Império. Em áreas mais próximas do Rio de Janeiro e de intensa ligação mercantil com a praça carioca, como parte das Províncias de Minas e São Paulo, essas influências, que continuaram ao longo da segunda metade do século XIX (FARIA, 2002; ALENCASTRO, 1997; FREYRE, 1965), puderam ser percebidas com maior clareza (LENHARO, 1979).

Primeiramente, vejamos as indicações de mudança nos costumes apresentadas pelos bens de uso pessoal, utensílios domésticos e "trastes" existentes no interior das moradas sul-mineiras ao longo da primeira metade do século XIX. 
Quadro 1

Proporção dos bens de uso pessoal, utensílios domésticos e do interior das moradas nos inventários com 20 escravos ou mais - Campanha (1803-1865)

\begin{tabular}{|c|c|c|c|c|c|c|}
\hline \multirow[t]{2}{*}{ Itens } & \multicolumn{2}{|c|}{ 1803-1830 } & \multicolumn{2}{|c|}{$1831-1850$} & \multicolumn{2}{|c|}{$1851-1865$} \\
\hline & $\begin{array}{l}\text { N. de } \\
\text { Inv. }\end{array}$ & $\%$ & $\begin{array}{l}\text { N. de } \\
\text { Inv. }\end{array}$ & $\%$ & $\begin{array}{l}\text { N. de } \\
\ln v\end{array}$ & $\%$ \\
\hline Jóias & 3 & $50 \%$ & 14 & $43 \%$ & 13 & $50 \%$ \\
\hline Relógio de algibeira & 2 & $33 \%$ & 8 & $25 \%$ & 9 & $34 \%$ \\
\hline $\begin{array}{l}\text { Talheres e facas de } \\
\text { prata }\end{array}$ & 3 & $50 \%$ & 27 & $84 \%$ & 16 & $61 \%$ \\
\hline Aparelhos de chá & 2 & $33 \%$ & 6 & $18 \%$ & 4 & $15 \%$ \\
\hline Louças & & & 11 & $34 \%$ & 11 & $42 \%$ \\
\hline Mesa de jantar & & & 1 & $3 \%$ & 3 & $11 \%$ \\
\hline $\begin{array}{l}\text { Armário de guardar } \\
\text { roupa }\end{array}$ & & & 1 & $3 \%$ & 1 & $4 \%$ \\
\hline $\begin{array}{l}\text { Marquesas, cadeiras e } \\
\text { tambores com assento } \\
\text { de palhinha }\end{array}$ & & & 6 & $18 \%$ & 10 & $38 \%$ \\
\hline Escrivaninha & & & 2 & $6 \%$ & 1 & $4 \%$ \\
\hline Estante para livros & & & & & 1 & $4 \%$ \\
\hline Guarda-livros & & & 1 & $3 \%$ & & \\
\hline Oratório & 1 & $16 \%$ & 18 & $56 \%$ & 9 & $34 \%$ \\
\hline Relógio de parede & & & 1 & $3 \%$ & 10 & $38 \%$ \\
\hline Relógio de mesa & & & 3 & $9 \%$ & 1 & $4 \%$ \\
\hline Piano & & & 1 & $3 \%$ & 1 & $4 \%$ \\
\hline Quadros & & & 3 & $9 \%$ & & \\
\hline Livros & & & 1 & $3 \%$ & & \\
\hline Total de inventários & & & & & & \\
\hline
\end{tabular}

Fonte: Inventários post-mortem de Campanha. Centro de Memória Cultural do Sul de Minas (Cemec/SM).

Antes de analisar os dados apresentados, é preciso fazer algumas considerações sobre as fontes. Outros aspectos precisam ser destacados, que não somente a sub-representação dos inventários para o primeiro subperíodo 
(1803-1830). Como não disponho de inventários para o final da segunda metade do século XVIII, fica difícil perceber em que medida os inventários poderiam indicar sinais de mudanças nos costumes da elite nos anos que se seguiram à chegada da Corte. Por outro lado, como a maioria dos inventários se concentra no subperíodo posterior (1831-1850), será possível identificar algumas transformações nos hábitos da elite e até mesmo tendências que se confirmarão para o subperíodo seguinte. Outro aspecto a considerar é que estou tratando de uma elite escravista ambientada, em sua grande maioria, na área rural, embora quase sempre possuísse moradas nas vilas e arraiais próximos às sedes de suas fazendas. A idéia de rusticidade, de estilo de vida simples, pela qualidade e quantidade dos bens arrolados nos inventários, à primeira vista, parece confirmar as impressões de Saint-Hilaire. Mas os indicativos de mudanças nos hábitos e costumes de uma parcela da elite também podem ser percebidos a partir de um olhar atento ao conteúdo dos inventários.

As jóias poderiam, ao mesmo tempo, representar um investimento e denotar prestígio social, sendo geralmente utilizadas em cerimônias religiosas, profanas e civis. As jóias arroladas constituíam-se de cordões de ouro, laços com pedrinhas, brincos, colares, pulseiras, alfinetes, botões, anéis com pedras preciosas, e em alguns casos vinham arrolados até mesmo os anéis com pedras falsas. Foi o caso do inventário de Luiz Antônio Azevedo, realizado em 1817 , que possuía um anel de topázio, outro menor com duas pedras de diamante e um inferior "com pedra falsa" (Inv. 2). Algumas peças religiosas de uso doméstico, desde que ornamentadas com ouro e pedras preciosas, vinham arroladas como jóias. É o caso do inventário de Lauriana Gonçalves de Brito, de 1814, que possuía um rosário de ouro com cruz e uma imagem de Cristo com duas pedras (Inv. 1). No inventário do primeiro juiz municipal de Campanha, o desembargador José Joaquim Carneiro de Miranda da Costa, entre as suas jóias se destacavam um rosário de ouro, um cordão com uma imagem de Nossa Senhora da Conceição, um colar e uma cadeia de relógio com duas pedras (Inv. 13). Dona Maria Bento Carneiro, por exemplo, teve várias jóias arroladas e muitas de ouro e pedra. Em 1849, possuía três pares de botões de ouro e dois alfinetes, um par de pulseiras, um anel de pedra roxa, um dito amarelo, um par de brincos de pedra e um relógio de ouro (lnv. 14).

Como se constata no Quadro 1, a proporção de jóias encontrada nos três subperíodos não apresentou grande variação, sinalizando a importância socioeconômica que esses bens representavam para uma parcela da elite escravista. Mesmo depois da década de 1850 não há mudança significativa no padrão das jóias listadas nos inventários. Continuavam a ser mencionados os rosários, brincos, anéis, memórias, correntes, botões, alfinetes, etc.

O que pode ser destacado ao longo do século XIX é o aumento do número de relógios de algibeira que foram listados nos inventários, especialmente após 1850 . Esse tipo de relógio começou a fazer parte da indumentária masculina já nas primeiras décadas do século XIX. Eram de origem inglesa ou francesa. Os relógios de algibeira, ou "cebolões" (ALENCASTRO, 1997), que mais tarde seriam conhecidos popularmente como "relógios de bolso", quase sempre vinham 
acompanhados de uma corrente de ouro ou prata e até mesmo de pedras preciosas. $\bigcirc$ coronel Roque de Souza Magalhães, morador na Fazenda Pedra Branca, freguesia de Santa Catarina, em 1838, possuía um relógio de algibeira acompanhado de uma corrente de ouro (Inv. 8). Os relógios eram artigos importados que se tornaram ícones de prestígio e status. $\bigcirc$ tenente João Bernardes Pinto, em 1833, possuía um relógio de algibeira francês (Inv. 5). Rezende (1987) nos oferece uma descrição detalhada desse acessório de grande importância para muitos homens daquele tempo.

[...] relógios que pela sua forma e tamanho às vezes se chamavam cebolas: pois que além de serem muito grandes ainda estavam encerrados em uma grande porção de capas de prała que no abrir ou tirar muito se pareciam a uma cebola que se descasca; tendo esses relógios além da fita ou cordão de ouro que os segurava, um grande número de penderucalhos (sic) alguns dos quais se compunham de pedras mais ou menos preciosas (REZENDE, 1987, p. 212).

Embora os relógios de algibeira fossem se tornando cada vez mais comuns e fizessem parte da indumentária dos brasileiros, os exemplares que a elite possuía representava, muitas vezes, uma jóia de família que era repassada para as gerações seguintes. Ainda que a profusão dos relógios de algibeira introduzisse uma nova noção do tempo, essa mudança não afetou, de imediato, a disciplina do trabalho, como brilhantemente demonstrou Thompson (1998) ao empreender uma discussão sobre o tempo, a disciplina do trabalho e a transição para a sociedade industrial na Europa.

As bocetas de prata vinham arroladas com as jóias e também estavam presentes na maioria dos inventários. Além do relógio de algibeira, o lenço e a boceta de tabaco faziam parte do vestuário masculino. $\bigcirc$ uso do tabaco era muito comum entre os diversos segmentos da população, sendo cheirado, pitado, fumado e mascado. As diferenças ficavam pelo tipo de fumo usado e a forma do uso. Segundo Rezende (1987), o cigarro era um vício comum nas classes baixas. Em todos os segmentos havia o costume de mascá-lo e cheirá-lo. $\bigcirc$ uso de cachimbos era comum entre os escravos. Mas o costume que predominava naqueles tempos era o de cheirar tabaco. E também havia diferenças pela qualidade e tipo de fumo utilizado. Daí a importância do uso das bocetas de prata, especialmente para os membros da elite. Antes da profusão das diferentes espécies de rapé, o fumo mais utilizado era o tabaco torrado e moído, na maioria das vezes em casa, conhecido como esturro, era o mais grosso. $\bigcirc$ mais fino e preparado com mais cuidado era conhecido por amostrinha. O terceiro era mais caro e somente poucos tinham acesso a ele. Era feito de um fumo especial, de cheiro mais agradável do que os dois primeiros. Segundo o autor, esse fumo era importado do litoral de São Paulo (REZENDE, 1987, p. 212-213).

Os utensílios domésticos, como talheres e facas de prata, aparelhos de chá e louças, tornaram-se cada vez mais freqüentes a partir da década de 1830, indicando que a maioria das famílias que detinha algum grau de riqueza poderia adquiri-los e até mesmo ostentá-los em ocasiões especiais. Não tenho como avaliar se a existência dos talheres implicava seu uso cotidiano durante 
as refeições. Também são listados talheres de ferro, que talvez fossem os mais utilizados no dia-a-dia pelos senhores e seus familiares. Pela proporção de talheres encontrados nos inventários, temos alguns indícios acerca da inserção das "boas maneiras" de como se comportar à mesa. Evidentemente que essas mudanças foram mais perceptíveis nos núcleos urbanos importantes do Império, especialmente na Corte. Ali, o contato e a influência dos costumes europeus ganhavam cada vez mais espaço, e o ideal de civilização era interpretado como progresso e estratégia para distanciar a elite do mundo da escravidão. A busca pela combinação do ideal aristocrático com o progresso e a modernidade foi observada, especialmente, entre os grandes cafeicultores do Vale do Paraíba, na segunda metade do século XIX. Esses aspectos poderiam ser detectados tanto no estilo neoclássico de construção das fazendas como nos objetos de decoração existentes no interior das casas, no uso cada vez maior de utensílios de prata e porcelana, além do número de escravos empregados em atividades domésticas e até mesmo como integrantes de bandas de música (CASTRO; SCHNOOR, 1995; FARIA, 2002, p. 141-143).

Segundo Elias (1994), o termo civilização começou a ser empregado na França a partir de meados do século XVIII, com o objetivo de demarcar as diferenças socioculturais da nobreza e da burguesia em ascensão em relação aos hábitos rústicos das populações pobres e rurais. Dentre os instrumentos que sinalizavam esse ideal de civilidade destacavam-se os manuais de bons costumes, de higiene, dos bons modos à mesa, do vestuário, etc. No século XIX, esses manuais tiveram larga aceitação entre uma parcela da elite no Brasil (ABREU, 2002).

Ainda que o cenário das fazendas mineiras tenha sido marcado pela rusticidade no interior das moradas, no vestuário e mesmo na simplicidade dos costumes, uma parcela da elite tinha acesso aos bens importados e procurava exacerbar esse sentimento aristocrático que a diferenciava dos outros segmentos da população livre. Em 1853, dona Maria Teresa do Carmo, por exemplo, possuía um aparelho de chá de louça azul, uma dúzia e meia de pratos grandes, de beira azul, compoteiras de louças, xícaras pintadas, travessas de mesa, sopeira azul e cálices pequenos para servir vinho (Inv. 15). Esse também parece ter sido o caso de Maria Antônia de Jesus, que, em 1833, possuía duas dúzias de louças de beira verde, uma branca usada, sete pratos e travessas com beira branca usados, seis copos de vidro, cinco pares de pires e de xícaras amarelas (Inv. 6).

Vimos pelo depoimento de Saint-Hilaire (1 976) que o interior das fazendas mineiras era marcado por grande rusticidade. Os móveis se restringiam a poucas mesas, algumas cadeiras e alguns bancos. Mesmo na moradia daqueles senhores que eram tidos como os mais abastados pelos moradores de determinada povoação, a rusticidade das acomodações causou espanto ao botânico francês. Pelos inventários pesquisados percebe-se que, em parte, Saint-Hilaire tinha razão. Como já comentei anteriormente, quase todo grande proprietário possuía uma morada de casas na vila mais próxima. E é justamente comparando o interior das sedes das fazendas e das moradas nas vilas que podemos perceber certas 
diferenças e como, aos poucos, a importância que certo mobiliário passou a adquirir entre os mais abastados. Aí também se inclui os objetos de decoração e o vestuário, tanto o de uso pessoal quanto as roupas de cama, de mesa e banho. Para tecer essas considerações partirei de alguns inventários em que a descrição desses bens aparece de forma mais detalhada.

Antes de tudo, é preciso chamar a atenção para o fato de que grande parte dos inventários consultados não distingue os objetos que havia nas sedes das fazendas dos das moradias nas vilas. Muitas vezes, vinham descritos genericamente como uma morada de casas no arraial "com todos os seus pertences". José Carvalho de Mourão, por exemplo, teve seus bens inventariados em 1844. Possuía uma morada de casas na Rua da Áustria, em Campanha, coberta de telha, com quintal e "mais pertences" (Inv. 12).

Em casos mais raros, essa descrição vinha em separado, o que permite ao historiador detectar algumas diferenças no mobiliário e nos objetos de uso pessoal existentes nos dois tipos de moradia. É o caso do inventário da sogra do barão de Pouso Alto, realizado em 1855 (Inv. A). Dona Isabel Maria do Espírito Santo acumulou a maior fortuna que consegui localizar para os proprietários do termo de Baependi. Grande parte do sucesso de seus empreendimentos contou com a participação e sociedade de seu sogro, o sargento-mor Francisco Teodoro da Silva (barão de Pouso Alto), que também foi um dos seus inventariantes. Os bens inventariados totalizaram mais de 400:000\$000 (quatrocentos contos de réis), destacando-se numerosa escravaria para os padrões da época, que ultrapassava o número de 270 cativos. Como a maioria dos grandes proprietários sul-mineiros, a riqueza amealhada ao longo da primeira metade do século XIX tinha ligação estreita com a produção de gêneros voltados para o abastecimento interno e com a praça mercantil carioca, além disso, os proprietários também se dedicavam à produção e ao comércio de fumo.

Para sorte do historiador, seus bens foram discriminados em separado, tanto nas várias fazendas que possuía quanto no sobrado da família existente na vila de Pouso Alto, o que, certamente, ajuda a perceber as semelhanças e diferenças entre o que havia no interior das diferentes residências. No início da descrição dos seus bens, vem arrolado um aparelho de prata com as seguintes peças: um jarro, uma bandeja, um bule, uma cafeteira, uma leiteira, um açucareiro, uma manteigueira, um faqueiro completo, com três dúzias de talheres, além de quatro castiçais. Depois é que aparece a descrição dos bens em separado por fazendas e na morada em Pouso Alto. A título de comparação e para não cansar o leitor, escolhi os bens existentes numa das fazendas mais importantes da família, a dos Pessegueiros, comparando-a com o que existia no sobrado de Pouso Alto. A princípio, o que chama a atenção é a qualidade dos móveis existentes no sobrado da vila, cuja descrição, embora mais econômica, mostra que eram móveis melhores.

Na Fazenda Pessegueiros, por exemplo, havia uma cômoda com duas gavetas, cinco mesas de pinho ordinárias, três aparadores, oito tambores usados, 18 cadeiras (10 com acento de sola e oito de palhinhas ordinárias), 
um armário grande, quatro caixas grandes de pinho, dois espelhos, duas jarras pequenas, um relógio de mesa parado, louças, um par de canastras usadas e 14 rodas de fiar. Já no sobrado de Pouso Alto havia dois sofás, quatro aparadores, uma mesa de meio de sala, 12 cadeiras de palhinha, um catre de armação, quatro castiçais de casquinha velhos e várias peças de louça. Ainda foi mencionado, genericamente, a existência de objetos de decoração como quadros e espelhos.

A descrição dos objetos de vestuário e de uso pessoal também foi mais econômica para a moradia na vila, embora seja possível especular que as melhores roupas de cama e mesa estivessem naquela residência. Na Fazenda Pessegueiros foram descritas genericamente várias roupas de cama e toalhas de mesa e de mão. Também foram arroladas 540 varas de algodão grosso, 89 varas de riscado, 33 mantas inglesas, 31 côvados de baeta vermelha e 14 paus de barbante. $\bigcirc$ algodão, provavelmente, era utilizado para a confecção de tecidos grossos que vestia a numerosa escravaria ${ }^{7}$. Em Pouso Alto, havia duas colchas de damasco, roupas de cama, de mesa e de mão e uma rede. Provavelmente, o sobrado da vila e o que havia em seu interior pudessem apresentar sinais claros de diferenciação social e até mesmo certo nível de ostentação da riqueza acumulada pela família ao longo da primeira metade do século XIX.

Em alguns inventários as roupas de cama, de mesa e toalhas de mão vêm descritas de modo mais detalhado. $\bigcirc$ guarda-mor José da Costa Rios, dono de engenho na freguesia de São Gonçalo, possuía lençóis de paninho com colcha de seda, uma colcha de chita forrada de baeta e uma colcha de lã. No inventário do filho do casal, realizado em 1840, também são arroladas seis camas com colchas de chita e cinco com cobertores espanhóis (Inv. 7). Maiores detalhes sobre os artigos de tecidos utilizados em casa, tais como toalhas, guardanapos, lençóis, aparecem com maior freqüência entre aqueles que possuíam propriedades na vila, como é o caso de dona Maria Antônia de Jesus, já mencionada, moradora na Fazenda Pitangueiras e proprietária de uma casa em São Tomé das Letras. Entre seus bens são arrolados seis toalhas de mesa, algumas delas de tecido fino e bordadas, além de toalhas de mão e guardanapos. No inventário do tenente João Bernardes Pinto e Maria Cristina dos Reis (1 833), foram arrolados seis lençóis de paninho, dois de algodão americano, cinco de algodão com babados, 11 de algodão grosso, seis colchas de baeta usadas, três de chita, quatro cobertas de lã grossa, dois cobertores de algodão grosso pintados, oito toalhas grandes de mesa, 14 de mão e 24 guardanapos (Inv. 5). Em alguns inventários as roupas de cama são descritas de forma bastante genérica, como no caso do inventário de dona Francisca de Paula Gualdino de Resende (1833), em que são descritas oito camas "com seus pertences" (Inv. 4).

Quanto ao mobiliário existente nas moradias das famílias mais abastadas, o quadro apresentado indica a freqüência cada vez maior do uso de marquesas, tamboretes e cadeiras de palhinha. Esse tipo de móvel estava presente também nas fazendas, mas os melhores e mais novos vinham listados, quase sempre, nas moradias existentes nas vilas. Foi o caso do desembargador 
José Joaquim Carneiro de Miranda da Costa, iá mencionado, que possuía uma marquesa de palhinha e outra de tábua, três mesas, três catres, duas cômodas, um oratório com uma imagem do Senhor crucificado e uma mesa com duas gavetas.

Os oratórios também poderiam figurar como peças de decoração e até mesmo de ostentação, embora tenham muito mais a ver com a tradição religiosa mineira que remonta ao século XVIII. Estavam presentes em grande parte das residências dos proprietários mineiros, especialmente nas fazendas. O capitão José Pinto Ribeiro, por exemplo, morador no arraial da capela do Rio Verde possuía, em 1831, um oratório com oito imagens, dois castiçais e uma campainha (Inv. 3). Na segunda metade do século XIX, os oratórios ainda possuíam um espaço significativo nas residências mineiras. Nas mais abastadas, eles poderiam apresentar maior requinte e tamanho (Figura 15, oratório da Fazenda Campo Lindo). Valeriano Manso da Costa Reis, por exemplo, em 1864, deixou para seus herdeiros um oratório grande de Santa Luzia do Sabará (Inv. 16).

Outras propriedades possuíam capelas contíguas às casas de vivenda e em casos mais raros eram separadas da propriedade, como é o caso da capela de São José do Favacho, de propriedade da família Junqueira (Figuras 18 e 19). Em fazendas que possuíam capelas contíguas ou separadas, os ornamentos dos altares vinham descritos com detalhes, por exemplo, cálices, missais, casulas, estolas, toalhas para o altar (Figura 29, capela da Fazenda Angaí). No inventário de Ana Josefa Dias, moradora na freguesia de São

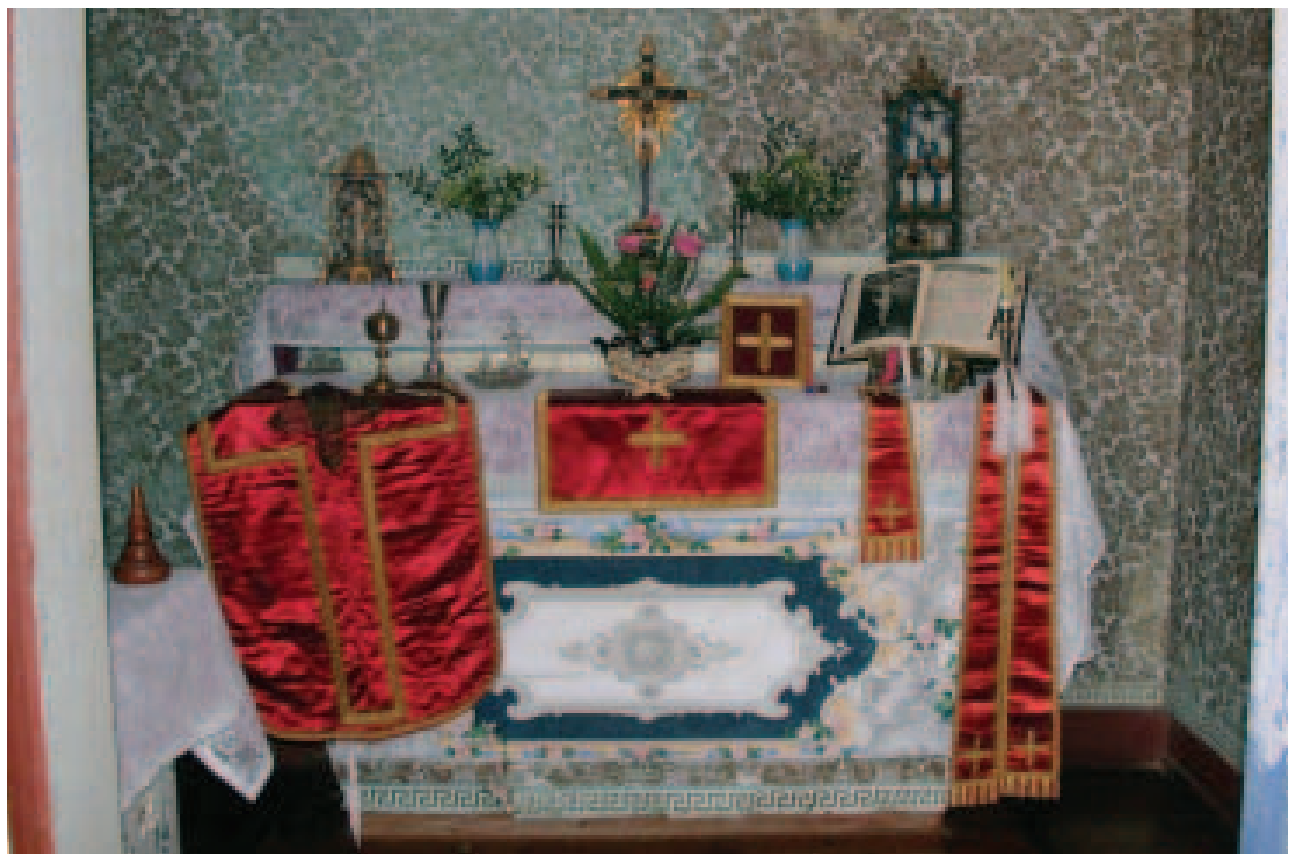

Figura 29 - Pequena capela que existe dentro da Fazenda Angaí, com imagens, cálices, patenas, missais, toalhas e paramentos. Acervo particular do dr. José Américo Junqueira de Mattos. Foto de Verissimo João Dias Neto (Lilo). Nov./2003. 
Gonçalo, em 1842, também aparece uma descrição detalhada dos objetos que faziam parte da capela que havia dentro de sua residência (Inv. 10).

Sem dúvida, o inventário da esposa do barão do Rio Verde constitui um dos documentos mais preciosos para se verificar as mudanças que se operavam nos hábitos e costumes de uma parcela da elite escravista, com acesso a certos bens de consumo mais comuns de se vislumbrar na Corte (Inv. 1 1). Não se trata aqui de estabelecer generalizações para a elite regional sul-mineira, ao contrário, quero demonstrar os diferentes caminhos encontrados por algumas famílias no sentido de combinar o ideal aristocrático com o progresso e a modernidade, preservando a estrutura escravista. $O$ barão do Rio Verde possuía uma fábrica de chapéus finos em São Gonçalo do Sapucaí. Grande parte da sua produção era exportada para a Corte. Como era de se esperar, combinava o trabalho livre com o escravo em sua fábrica. Até que ponto o interior de sua residência trazia indícios das transformações que se verificavam nos hábitos e costumes da elite escravista sul-mineira?

Adentremos em sua residência para vasculhar os sinais dessa mudança. Não será tarefa muito difícil, pois os louvados foram bastante generosos na descrição de alguns objetos existentes no interior de seu sobrado, em São Gonçalo do Sapucaí. Dentre esses bens, verificou-se certo requinte nos de uso pessoal, nos utensílios domésticos, móveis e objetos de decoração. Os proprietários possuíam um relógio de ouro inglês, além de vários objetos de prata como castiçais, faqueiro completo e colheres. Possuíam ainda um aparelho de chá de prata com seis peças, bules, leiteira, cafeteira, manteigueira, açucareiro e tigela, "tudo novo", além de três salvas e um paliteiro. Como objetos de decoração, destacavam-se oito quadros grandes que ficavam na sala, dois retratos grandes, dois vasos de cristal para flores, um espelho de sala, um oratório e seus pertences e um relógio de mesa. Alguns quadros foram descritos para a felicidade do historiador e permite especular sobre a orientação política do proprietário. Certamente era partidário das idéias republicanas, uma vez que possuía dois quadros da Declaração da Independência, mais um com o ato escrito da Independência Americana e outro com os seis presidentes americanos. No mobiliário destacavam-se 12 cadeiras de mola, 12 cadeiras de cabiúna novas e 12 cadeiras americanas, um sofá, uma mesa redonda e uma mesa de sala de espera. Possuía ainda uma mesa para escritório e uma escrivaninha, móvel indispensável em uma biblioteca e certamente utilizado para realizar as suas "escritas" referentes à sua fábrica de chapéus.

Algumas evidências de mudanças nos costumes e até mesmo de certo conforto na residência podem ser percebidas pela menção a três lavatórios e a uma mesa de barbear. O proprietário também possuía uma biblioteca "292 volumes de livros encadernados", de diferentes obras que, infelizmente, não foram discriminadas.

As roupas de cama, mesa e banho existiam em quantidade razoável. Foram listados 20 lençóis de linho novos e mais 20 usados, 10 fronhas grandes de paninho, duas para almofadas, 10 travesseiros, dois cobertores de lã, seis toalhas grandes de algodão, duas de linho, 12 guardanapos, 12 de algodão, 
12 toalhas de linho de mão, 12 ditas de pé, 30 mantas de lã, três peças de morim fino e uma peça de brim fino.

A importância que tinha o sobrado pode ser inferida pelo seu valor de avaliação em comparação ao estabelecimento onde funcionava a fábrica. sobrado foi avaliado em 8:000\$000 (oito contos de réis), enquanto a sede da fábrica, com todos os seus utensílios, foi avaliada em $1: 050 \$ 000$ (um conto e seiscentos e cinqüenta mil réis).

Os relógios de mesa e de parede também foram objetos cada vez mais comuns no interior das casas de morada (Figura 30 - relógio de parede da Fazenda do Favacho). Percebe-se que após a década de 1850, os relógios de parede, assim como os de algibeira, apareciam com maior incidência nos inventários. E como já afirmei anteriormente, a sua utilização estava mais relacionada aos costumes vigentes na Corte, que por sua vez tiveram influências dos costumes europeus, do que propriamente uma mudança na noção de tempo com conseqüências na disciplina do trabalho. $O$ tempo do trabalho nas fazendas ainda continuava sendo regido pelo romper da aurora e o pôr-do-sol e, dependendo da atividade, poderia entrar noite adentro.

p piano era outro objeto que também só podia ser acessível a uma parcela da elite, especialmente por ser um artigo caro e importado. Dentre os 64 inventários analisados em nossa amostra, somente dois mencionam a existência desse instrumento musical (Quadro 1). Também não se podem desconsiderar os signos de modernidade e diferenciação social de que era portador para aquelas

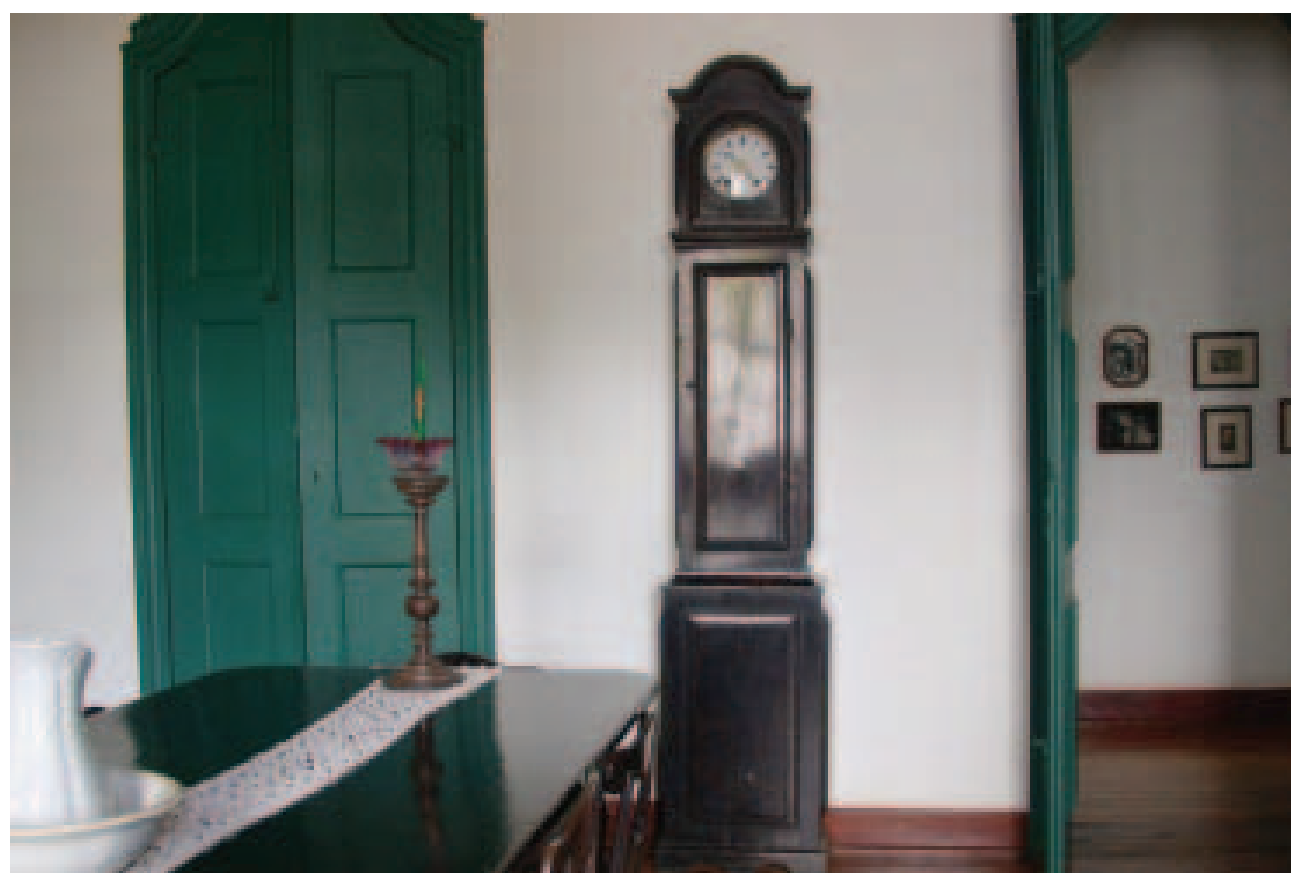

Figura 30 - Relógio de parede da Fazenda do Favacho. Acervo particular do dr. José Américo Junqueira de Mattos. Foto de Verissimo João Dias Neto (Lilo). Nov./2003. 
famílias que o possuíssem. Poderiam ser utilizados durantes os bailes e quando se cantavam modas e árias em algumas casas mais abastadas, onde tal tradição ocorria. É o que nos informa Rezende (1987) sobre esse costume na casa de seu avô. Além das razões apontadas, é preciso chamar a atenção para o alto custo e dificuldades no transporte dessa mercadoria, uma vez que todos artigos que chegavam ao sul de Minas vinham em lombo de burros. $\bigcirc$ nosso memorialista foi atento ao registrar esse aspecto, ressaltando a raridade desse artigo nas casas dos campanhenses mais abastados por causa das dificuldade no seu transporte.

Nos bailes de meu Avô tocava-se também piano e creio que se cantavam modas e árias; mas isso só se dava em casa dele; porque tendo hoje a Campanha dezenas de pianos, naquele tempo só havia esse de meu Avô que era um piano de cauda e de uma cauda tão comprida que ocupava boa parte da sala; e pode-se fazer idéia da dificuldade que não deveria haver para se conduzir uma peça destas por meio de animais e de uma tão grande distância e por tão maus caminhos como os que então existiam entre a Campanha e a Corte (REZENDE, 1987, p. 195) (grifo meu).

autor escreve suas memórias no final da década de 1880, um período em que a ferrovia estava em expansão no sudeste do Império e também atingia o sul de Minas. Em 1884, The Minas and Rio Railway Company concluiu a linha que ligava Cruzeiro (entroncamento da Estrada de Ferro D. Pedro II) a Três Corações. Em 1886 inaugurou-se o ramal de Poços de Caldas pertencente à Cia. Mogiana. Certamente, a chegada da ferrovia provocou uma grande redução nos custos e no tempo de transporte de vários artigos consumidos pelas principais famílias do sul de Minas. Nessa época, os pianos poderiam ser encontrados com maior facilidade no interior das residências mais abastadas da região.

Muitos dos núcleos urbanos das Minas Gerais do Oitocentos foram descritos superficialmente como as vilas de domingo. A difusão dessa expressão pode ser atribuida a Deffontaines (1938) em seu estudo sobre a constituição das redes de cidades no Brasil ${ }^{8}$. Saint-Hilaire (1974), ao passar por várias vilas e arraiais da província de Minas, acaba reiterando essa afirmação, com base em sua própria percepção e nas informações dos curas com os quais teve contato. Como já afirmei anteriormente, o relato dos viajantes deve ser lido com cuidado. Nem sempre aquilo que é dito é o que parece ser. Em sua passagem por vários distritos mineiros, o autor nunca deixou de mencionar a população que estava presente na vila durante a semana, embora quase sempre a desqualificasse social e moralmente. Em alguns momentos, o autor reiterou a presença de artífices e pessoas que viviam do comércio, mas não deixava de apresentar um olhar estereotipado sobre a população "de cor" e as prostitutas. Outro ponto a destacar é que a descrição do local visitado variava de acordo com a forma com que o viajante era recebido. Se the recebiam bem, não cansava de tecer elogios e a descrição poderia ser mais detalhada. Caso contrário, percebe-se claramente o aborrecimento do autor e um olhar carregado de muitos preconceitos.
8. Hipótese levantada por Da Mata (2002) em seu estudo pioneiro sobre a gênese dos antigos arraiais e vilas mineiras, resultado de uma tese de doutorado recentemente publicada. 
Algumas vilas mais urbanizadas como a de São João del-Rei e Barbacena mereceram maior atenção do autor.

Foi construída no cume de duas colinas extensas das quais uma concorre perpendicularmente para o meio de outra e compõe-se de duas ruas compridas. A igreja paroquial ocupa o centro de uma praça formada pelo encontro de duas ruas. Além desta igreja, existem três outras das quais ainda não terminada.

As casas são baixas e pequenas, mas bem bonitas. Cinco ou seis têm um andar além do térreo, e entre estas, existe uma que se torna notada pela bela parreira que the cobre a fachada. Vêem-se em Barbacena várias lojas bem sortidas, diversas vendas e algumas estalagens. Em nenhuma vila nesta Capitania é a mão-de-obra tão cara quanto aqui. Isto provém do fato de ser ela incessantemente atravessada por viajantes que ansiosos por alcançar seu destino deixam que os operários the ditem leis. Barbacena é célebre entre os tropeiros, pela quantidade de mulatas que nela habitam e entre as quais deixam os homens o fruto do trabalho (SAINT-HILAIRE, 1974, p. 39-40).

Já para a vila de Aiuroca, a descrição do autor parece bastante contraditória. Apesar de confiar nas informações do cura do lugar, ele não deixa de comentar a existência de lojas de comércio, de uma população que morava na vila e até de uma farmácia.

[...] compõe-se de cerca de oitenta casas. Constituem elas três ruas, cuja principal é bastante larga e paralela ao rio. A igreja paroquial ergue-se na extremidade mais elevada desta rua, é pequena, sem sino, e nada oferece de notável. Vêem-se além dela uma capela e outra igreja recentemente construída pela irmandade do Rosário e colocada num morro que domina toda a cidade. Como quase todas as aglomeraç̃eses de Minas, parece muito pouco habitada nos dias úteis. Torna-se, porém, provavelmente muito mais movimentadas nos domingos e feriados. Prova de que nem vive tão deserta quanto hoje é o fato de possuir algumas lojas bem regularmente sortidas, vendas e até mesmo uma farmácia. (grifo meu)

[...] Segundo o que me disse o cura, as conjeturas que formava ontem sobre a população desta cidade estão perfeitamente fundadas. Não é habitada durante a semana senão por mercadores, operários e prostitutas. Mas aos domingos e dias de festa, torna-se um lugar de reunião para todos os agricultores da comarca (SAINT-HILAIRE, 1974, p. 53).

Sobre a vila de Baependi, o botânico não ofereceu muitas informações. Fica situada à encosta de uma colina pouco elevada e compõe-se de várias ruas desiguais e irregulares. As casas que a margeiam são, em geral, muito pequenas e estão longe de atestar opulência. A igreja, construída numa praça pública, nada tem de notável (SAINT-HIILAIRE, 1974, p. 60).

Nosso viajante tinha planos de ir até a vila de Campanha, mas mudou de rota para não prolongar o seu trajeto em direção à Corte, preferindo seguir viagem pelo Registro Mantiqueira, um caminho mais curto em direção ao Rio de Janeiro. Depois se arrependeu amargamente do caminho escolhido em virtude da sinuosidade dos caminhos na Serra da Mantiqueira.

Em Pouso Alto, não conseguira um pouso decente para pernoitar. Sua descrição da vila acabou sendo muito resumida, com poucas informações e com alguns equívocos, considerando a vila como cidade e sede de comarca, o que ainda não era realidade em 1822. Como se tratava de uma vila que estava 
a meio caminho das Províncias de Minas Gerais, Rio Janeiro e São Paulo, produtora de fumo e rota de tropeiros, certamente a descrição do viajante não condiz com a realidade. Essa vila possuía um grande contingente populacional já nas primeiras décadas do século XIX, demonstrando a importância do lugar e sua conexão com atividades agropastoris e comércio de gêneros voltados para o abastecimento interno.

Paramos na cidade de Pouso Alto, sede de comarca. Está construída em anfiteatro, no declive de uma colina e representa como que uma pirâmide cuja igreja forma o vértice. A colina avança entre duas montanhas cobertas de mata e no sopé corre um riacho num pequeno vale (SAINT-HILAIRE, 1974, p. 64).

E o viajante acaba reforçando o preconceito presente nas descrições anteriores acerca da população que vivia nas vilas e distritos durante a semana. "As cidades, como já o disse, são apenas povoadas, durante a semana, pela mais vil canalha; alguns artífices, em sua maioria homens de cor, mandriões e rameiras" (SAINT-HILAIRE, 1974, p. 65). Também há de se considerar a profusão de vendas na região de Pouso Alto e o fato de que, por ser uma vila que estava na rota dos tropeiros, deveria ser muito movimentada durante toda a semana, e não só aos domingos e nos dias de festas.

No final do ano de 1836, quando já se encontrava no ostracismo político, Evaristo Ferreira da Veiga fez a sua primeira e única viagem a Minas Gerais, com o objetivo de visitar seus dois irmãos que residiam em Campanha desde a segunda década do século XIX. Durante os quase três meses que ficou em companhia de seus irmãos Lourenço Xavier da Veiga e Bernardo Saturnino da Veiga, escreveu várias cartas a seu irmão João Pedro, que ficara no Rio. Depois de passar alguns meses na vila de Campanha e de ainda visitar Baependi, não deixou de registrar suas impressões sobre os distritos e vilas da região, que formavam parte de sua base política no interior da Província de Minas e que the garantiam apoio no parlamento nacional.

Sobre Baependi, Evaristo não traz muitas informações. Só comenta que a povoação era um pouco menor do que a de Campanha e que a maioria dos moradores se ocupava da agricultura.

Viemos visitar esta vila, aonde (sic) estamos há quatro dias, tendo sido cordialmente acolhidos. É vila pouco menor que a da Campanha, e cuja população existe quase toda espalhada pelos arredores, ocupada na agricultura (4/3/1837- BN. 1-2).

Já sobre a vila de Campanha o relato foi mais detalhado. Informou sobre o número de casas, sobre as ruas e o estado ruim do seu calçamento. "A Vila terá coisa de quatrocentas casas, as ruas são mal calçadas, tortas, em subidas e descidas, e no tempo das chuvas é preciso cuidado ao andar por elas para não se escorregar." Evaristo se encontrava muito gordo e barrigudo nessa época e, com certeza, tinha dificuldades para caminhar, especialmente por ruas sinuosas de aclive um pouco acentuado. Não escondia o desconforto físico em que se encontrava. Chegou a comentar com o irmão João Pedro que 
seu sobrinho e afilhado, filho de Lourenço, residente em Campanha e que nunca tinha visto o tio-padrinho, fez o seguinte comentário: "que homem é este tão barrigudo?" (13/12/1836 - BN. I-2). Evaristo nunca tinha saído da Corte. $\bigcirc$ seu parâmetro de cidade e de calçamento de ruas era o do Rio de Janeiro. Evidentemente que ele não esperava encontrar uma situação semelhante nas vilas interioranas mineiras. Para quem vinha de uma cidade litorânea, onde grande parte da cidade se encontrava na parte plana, os aclives não tão acentuados da vila de Campanha não deixariam de representar certo desconforto.

Além da diversidade socioeconômica, profissional e cultural, as vilas também possuíam os conhecidos pontos de comércio fixo, denominados de lojas de secos e molhados. Nem sempre os inventários constituem a melhor fonte para esse tipo de investigação, a não ser quando o inventariado é um lojista, cuja mercadoria de seu estabelecimento tenha sido arrolada com minúcia pelos louvados. As cartas pessoais constituem uma outra boa fonte para esse tipo de investigação, especialmente quando se trata de correspondências de negociantes. Porém, esse não é o caso, embora as cartas de Evaristo também ofereçam indícios de alguns produtos que só poderiam ser adquiridos pela elite como bonecas francesas e brincos, apresentando bons indícios sobre alguns produtos que poderiam ser consumidos por parte da elite campanhense. Em relação ao número de bonecas encomendadas, certamente o autor estaria presenteando suas sobrinhas e prováveis afilhadas.

Para aí parte um dos genros do Mano Bernardo e por ele the remetemos o João. Pelo acima dito, pode você remeter-me 6 ou 8 bonecas francesas, mas que não sejam caras, assim como dois pares de brincos de filigrama, cujo preço não exceda a $20 \$$ r. cada par $(18 / 12 / 1836-B N .1-2)$.

Lourenço Xavier da Veiga, um dos irmãos de Evaristo que residia em Campanha, possuía uma casa de negócios de secos e molhados. Na mesma carta citada acima, no verso, há uma carta de Lourenço informando ao irmão residente no Rio de Janeiro que havia chegado somente parte do material solicitado e que ainda havia alguns artigos nas residências da família, na Corte.

O que veio agora pela última tropa ainda não é tudo o que estava pronto: faltando uma caixa de Los. [livros?], uns ferros de lampiões, que estavam no Miranda, vieram só parte, e um fogareiro de ferro, 1 tacho pequeno e dois ferros de alfaiate, e estas últimas coisas ficaram em sua casa ou na casa de Evaristo (18/12/1836 - BN. 1-2).

Como não se trata de grande quantidade de artigos não dá para perceber se os produtos seriam comercializados em seu estabelecimento ou se era para o seu próprio consumo.

Ainda que grande parte dos proprietários rurais se visse compungida a um contato cada vez mais estreito com seus cativos, naquele tempo, era muito marcante o sentimento aristocrático que pairava entre muitos deles, apesar da aparente rusticidade das casas e do interior das moradas dos mineiros mais abastados. $\bigcirc$ que se pode depreender dos casos analisados é que uma parcela 
da elite tinha acesso aos produtos importados da Corte, e os sinais de mudança, distinção e diferenciação social poderiam ser percebidos nos vestígios de sua cultura material registrados nos inventários, especialmente; no estilo de construção de algumas casas de vivenda e de morada e no que havia em seu interior.

REFERÊNCIAS

Fontes Manuscritas

1. Centro de Memória Cultural do Sul de Minas (CEMEC/SMCampanha/MG).

1. 1. Inventários Campanhenses (1803-1865) - 64 inventários

Lista nominal dos inventários citados

Inv. 1 - Lauriana Gonçalves de Brito (1814), cx. 2.

Inv. 2 - Luiz Antônio de Azevedo (1817), cx. 3.

Inv. 3 - José Pinto Ribeiro (1831), cx. 5.

Inv. 4 - Franscisca de Paula Gualdino de Resende (1833), cx. 6.

Inv. 5 - João Bernardes Pinto (1 833), cx. 6.

Inv. 6 - Maria Antônia de Jesus (1 833), cx. 6.

Inv. 7 - Guarda-mor José da Costa Rios (1 834), cx. 7.

Inv. 8 - Coronel Roque de Souza Magalhães (1838), cx. 10.

Inv. 9 - Alferes João da Costa Rios (1840), cx. 11.

Inv. 10 - Ana Josefa Dias (1842), cx. 13.

Inv. 11 - Luíza Amália de Lemos (1843), cx. 15.

Inv. 12 - José Carvalho de Mourão (1844), cx. 16.

Inv. 13 - José Joaquim Carneiro de Miranda da Costa (1844). cx. 16.

Inv. 14 - Maria Bento Carneiro (1849), cx. 22.

Inv. 15 - Maria Teresa do Carmo (1853), cx. 28.

Inv. 16 - Valeriano da Costa Reis (1864), cx. 40.

2. Arquivo do Museu Regional de São João del-Rei (AMRSJDR), (São João del-Rei - MG).

Inv. A - Inventário de dona Isabel Maria do Espírito Santo (1855)

- Cartório de Baependi.

Inv. B - Inventário de Gabriel Francisco Junqueira (1868) - Cartório de Baependi. 
3. Biblioteca Nacional (BN - Rio de Janeiro)

Carta de Evaristo Ferreira da Veiga ao irmão João Pedro da Veiga, em 4/3/1837. BN. I-2.

ld., $13 / 12 / 1836$. BN. $1-2$.

ld., $13 / 121836$. BN. I-2.

ld., 18/12/1836. BN. I-2

Carta de Lourenço Xavier da Veiga a seu irmão João Pedro da Veiga. Campanha, 18/12/1836. BN. I-2.

\section{Arquivo Histórico Ultramarino (AHU - Lisboa)}

Requerimento do capitão José Vieira de Almeida, residente no sítio do Ingai Abaixo, freguesia de Baependi, termo da vila de São João del-Rei, comarca do Rio das Mortes, pedindo carta de confirmação de sesmaria de uma légua e meia de terra, não obstante ter passado três anos. 9/6/1766. Arquivo Histórico Ultramarino $(A H U)$ - Cons. Ultram. - Brasil/MG, cx. 88, doc. 4.

\section{REFERÊNCIAS}

ABREU, M. Civilização. In: VAINFAS, R. (Org.). Dicionário do Brasil Imperial. Rio de Janeiro: Objetiva, 2002. p. 141-143.

ALENCASTRO, L. F. Vida privada e ordem privada no Império. In: NOVAIS, F. A. História da vida privada no Brasil. São Paulo: Companhia das Letras, 1997.

ANDRADE, M. F. de. Rebeldia e resistência: as revoltas escravas na Província de Minas Gerais. 1996. 258 f. Dissertação (Mestrado) - Faculdade de Filosofia e Ciências Humanas, Universidade Federal de Minas Gerais, Belo Horizonte, 1996.

Rebeliões escravas na Comarca do Rio das Mortes, Minas Gerais: o caso Carrancas. AfroÁsia, Salvador, n. 21-22, p. 45-82, 1998-1999.

.Revolta de Carrancas. In: VAINFAS, R. (Org.). Dicionário do Brasil Imperial. Rio de Janeiro: Objetiva, 2002. p. 635-637.

BASTOS,A. D. J. Lendas e tradições da família Junqueira. São Paulo: Hucitec, 1980.

BRAUDEL, F. Civilização material e capitalismo: séculos XVXVIII. Tradução por Maria Antonieta Magalhães Godinho. Lisboa: Edições Cosmo, 1970.

BRIOSCHI, L. R. Família e genealogia: quatro gerações de uma grande família no Sudeste Brasileiro. 1985. 271 f. Dissertação (Mestrado) - Faculdade de Filosofia, Letras e Ciências Humanas, Universidade de São Paulo, São Paulo, 1985. 
BROTERO, F. B. Memórias e tradições da família Junqueira. 2. ed. São Paulo: Gráfica Canton Ltda., 1959.

BURKE,P. A cultura material na obra de Gilberto Freyre.In:FALCÃO,J.; ARAÚJO, R. M. O imperador das idéias: Gilberto Freyre em questão. Rio de Janeiro:Toopbooks, 2001. p. 55-70.

CASTRO, H. M. M.; SCHNOOR, E. (Orgs.). Resgate: uma janela para o Oitocentos. Rio de Janeiro: Topbooks, 1995.

DA MATA, S. Chão de Deus: catolicismo popular, espaço e proto-urbanização em Minas Gerais, Brasil. Séculos XVIII e XIX. Berlim:Wiss.Verl. Berlim, 2002.

DEFFONTAINES, P. Como se constituiu no Brasil a rede de cidades. Boletim Geográfico. n. 14, p. 141-148, 1944.

DIAS, M. O. S. A interiorização da metrópole (1808-1853). In: MOTA, C. G. (Org.). 1822: Dimensões. São Paulo: Perspectiva, 1972.

ELIAS, N. O processo civilizador. Rio de Janeiro:Jorge Zahar, 1994.

FARIA, S. C. A colônia em movimento: fortuna e família no Brasil Colonial. Rio de Janeiro: Nova Fronteira, 1998.

Modernização. In: VAINFAS, R. (Org.). Dicionário do Brasil Imperial. Rio de Janeiro: Objetiva, 2002. p. 537-539.

Barões do café. In: VAINFAS, R. (Org.). Dicionário do Brasil Imperial. Rio de Janeiro: Objetiva, 2002. p. 141-143.

FREYRE, G. Casa grande e senzala. 42. ed. Rio de Janeiro: Record, 2001.

.Sobrados e mocambos. 3. ed. Rio de Janeiro: José Olympio,1961.

Ingleses no Brasil. Rio de Janeiro: José Olympio, 1965.

HERING, A. F. et al. Arquitetura rural: fazenda Traituba. 1994. Monografia. Departamento de Arquitetura e Urbanismo, Pontifícia Universidade Católica de Minas Gerais, Belo Horizonte, 1994. (Mimeo.).

LENHARO, A. As tropas da moderação: o abastecimento da Corte na formação política do Brasil, 1808-1842. Rio de Janeiro: Símbolo, 1979.

LIBBY, D. C. Transformação e trabalbo em uma economia escravista: Minas Gerais no século XIX. São Paulo: Brasiliense, 1988.

MACHADO, A. Morte e vida do Bandeirante. 3. ed. Belo Horizonte: Itatiaia, São Paulo: Edusp, 1980.

MATTOS, J.A. J. de. Família Junqueira: sua bistória e genealogia. Rio de Janeiro: Ed. Família Junqueira, 2004.

NEVES, L. B. P.; MACHADO, H. O Império do Brasil. Rio de Janeiro: Nova Fronteira, 1999. 
NICOLIELLO, P. T.; CARVALHO, E. de B. Levantamento arquitetônico, histórico e reconstituição da fazenda Traituba. 1985. Monografia. Departamento de Arquitetura e Urbanismo, Universidade de Taubaté, Taubaté, 1985. (Mimeo.).

REZENDE, F. P. F. de. Minhas recordações. Belo Horizonte: Imprensa Oficial, 1987.

SAINT-HILAIRE,A. Segunda viagem do Rio de Janeiro a Minas Gerais e a São Paulo. Tradução por Vivaldi Moreira. Belo Horizonte: Itatiaia, São Paulo: Edusp, 1974.

Viagens às nascentes do Rio São Francisco. Tradução por Regina Regis Junqueira. Belo Horizonte: Itatiaia, São Paulo: Edusp, 1976.

STEIN, S. J. Vassouras: um município brasileiro do café, 1850-1900. Tradução por Vera Bloch Wrobel. Rio de Janeiro: Nova Fronteira, 1990.

THOMPSON, E. P. Tempo, disciplina e trabalho e capitalismo industrial. In: Costumes em comum: estudos sobre a cultura popular. Tradução por Rosaura Eichemberg. São Paulo: Companhia das Letras, 1998. p. 267-304.

Artigo apresentado em 08/2004. Aprovado em 1 1/2004. 